DEPARTMENT OF THE INTERIOR

UNITED STATES GEOLOGICAL SURVEY

CHARLES D. WALCOTT, DIRECTOR

\title{
THE DISPOSAL OF
}

\section{STRAWBOARD AND OIL-NELL WASTES}

BY

ROBERT LEMUEL SACKET'T

ANJ

\section{ISAIAH BOWMAN}

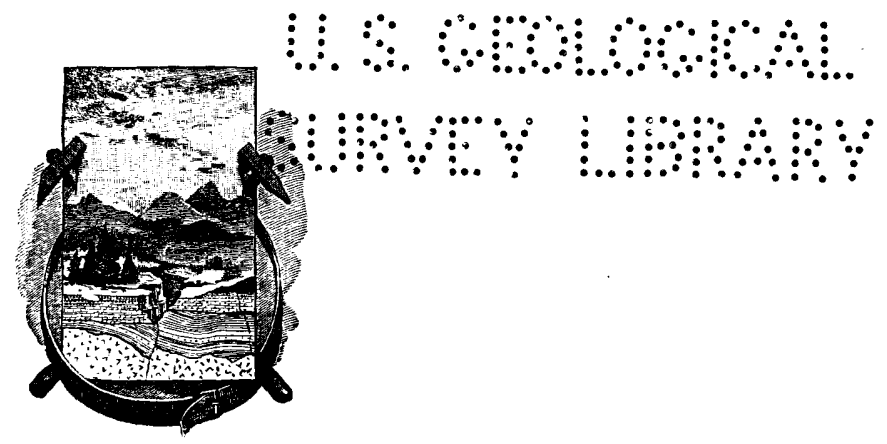

WA SH INGTON

GOVERNMENT PRINTING OFFICE

1905 
मओ औ 


\section{CONTENTS.}

LETTER OF TRANSHITTAL

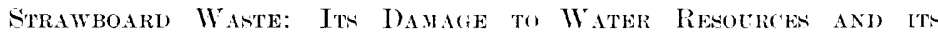
Economic DisPosil, BY R. L. SACKeTT.

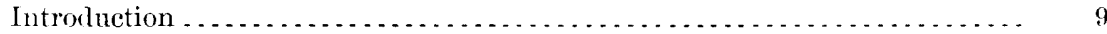

Sources and effects of stream pollution $\ldots \ldots \ldots \ldots \ldots \ldots \ldots \ldots \ldots \ldots \ldots \ldots \ldots . . . \ldots \ldots$

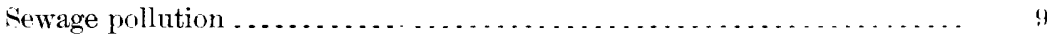

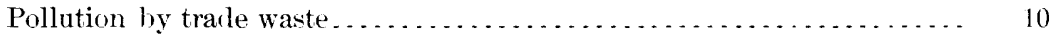

Manufacture of strawboard ... . . . . . . . . . . . . . . . . . . . . . . 11

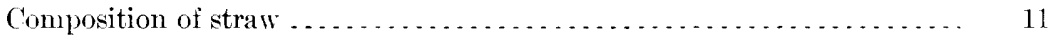

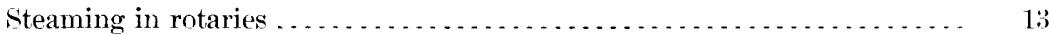

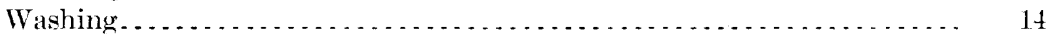

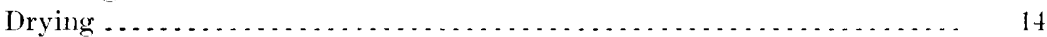

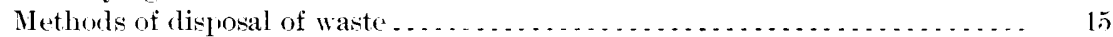

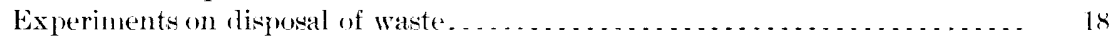

Methods of purification $\ldots \ldots \ldots \ldots \ldots \ldots \ldots \ldots \ldots \ldots \ldots \ldots \ldots \ldots \ldots$

Sedimentation ...................................

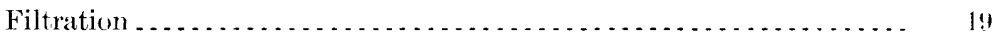

Chemical precipitation................................ 20

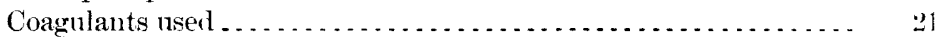

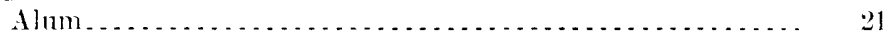

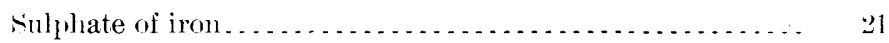

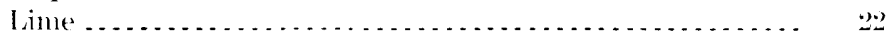

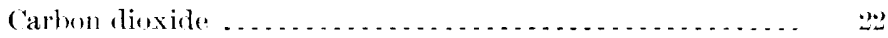

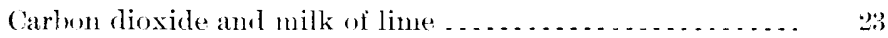

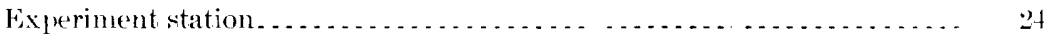

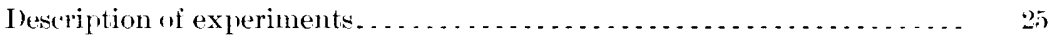

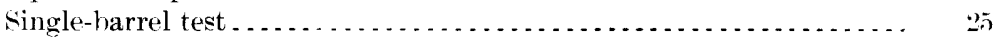

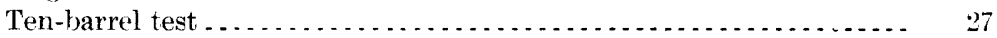

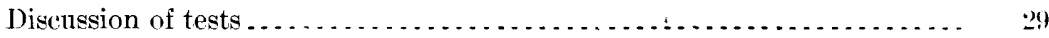

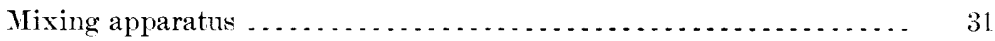

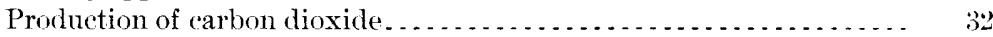

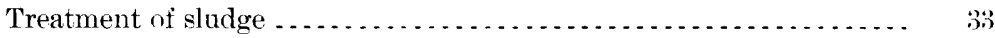

Conclusions . . . . . . . . . . . . .

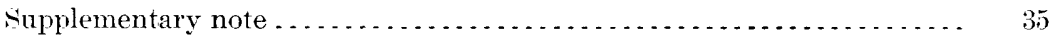

Disposal of Oil,wel, Wastes at Marion, Ind., By Isaiah Bowahn.

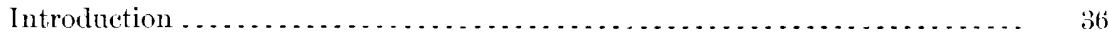

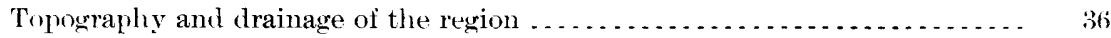

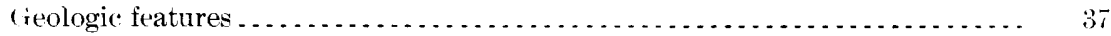

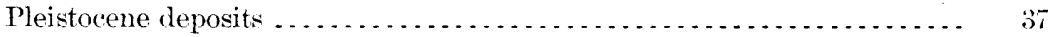

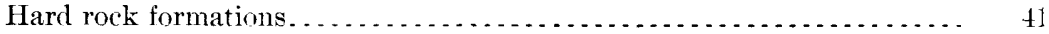

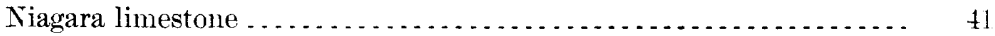

Hudson River limestone and Utica shale.................. 42

Trenton limestone... . . . . . . . . . . . . . . . . .

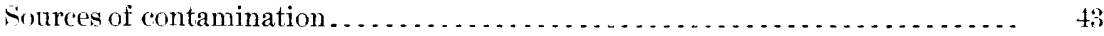

Supplementary note, by Marshall Ora Leightom . . . . . . . . . . . . . . . . . . 49

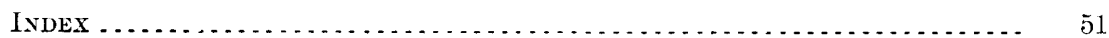





\section{ILLUSTRATIONS.}

I1. $A$, Pulp washers; $B$, Settling basins...................... 14

III. Settling basins and filter beds.......................... 16

IV. Receiving tank with discharge pipes ...................... 44

FIG. 1. Plan of strawhoard settling basin .......................... 17

2. Carbon-dioxide distributor..................................... 24

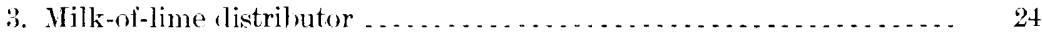

4. Map of Marion, Ind ........................................ 



\title{
LETTER OF TRANSMITTAL.
}

\author{
Department OF THE INTERIOR, \\ United States Geological Survey, \\ Washington, D. C.. Jamumy 87,1904 .
}

SiR: I have the honor to transmit herewith two manuscripts, the first entitled "Strawboard Waste: Its Damage to Water Resources and its Economic Disposal," by R. L. Sackett; the second, "Disposal of Oil-Well Wastes at Marion, Ind.," by Isaiah Bowman, and to request that they be published together as one of the series of WaterSupply and Irrigation Papers.

These papers include a part of the results of investigations made by the division of hydro-economics. The determination of the quality of available waters in the United States and their applicability to domestic and industrial uses involves a consideration of the principal sources of their pollution.

The subjects dealt with in these papers represent two particularly troublesome sources of damage to water resources. The areas in which such damage occurs are very large and important, pollution of the kind considered in the first paper covering the States of Ohio, Indiana, and Illinois, and that discusised in the second paper haring been felt in all those parts of the country in which oil wells have been developed.

These investigations were undertaken in an experimental way, and it is hoped that they may serve to direct wider attention to the problems involved, to the end that practical solutions may be reached which will be satisfactory to all those whose interests are involved.

Very respectfully,

$$
\begin{aligned}
& \text { F. H. NewnLL, } \\
& \text { Chief Engineer. }
\end{aligned}
$$

Hon. Charles D. Walcott,

Director United States Geological Survey. 



\section{STRAWBOARD WASTE: ITS DAMAGE TO WATER RESOURCES AND ITS ECONOMIC DISPOSAL.}

By Robert Lemuel Sackett.

\section{INTRODUCTION.}

Rivers and streams have a commercial value by which they have been universally rated, yet in many cases this rating must properly take into account more than strictly commercial or industrial uses. Water power or shipping facilities have often determined the location of a mill where a city was unforeseen, and the value of the stream as a source of water supply for culinary or drinking purposes has thus often been left entirely out of consideration. But watercourses contribute not only to the commercial value of a location, but to health, and their influence on health has now become an important factor in determining the money value of the lands bordered by them. Health and wealth are in some localities dependent on the condition and flow of streams.

All sanitary authorities now recognize the vital necessity of providing a pure source of municipal or private water supply. Family wells and springs can safely serve but a small proportion of the population. The urban population is now about 50 per cent of the total, and as it grows the percentage dependent on municipal supply will increase. It is to this class of water supplies that this discussion is confined.

\section{SOURCES AND EFFECTS OF STREAM POLLUTION.}

\section{SEWAGE POLLUTION.}

As the wilderness was subdued by the pioneer, small mills and towns were established on lakes, rivers, and streams. By cutting the forests and draining the cultivated and settled areas the character of the stream flow was changed. Forests are natural reservoirs, where the rainfall is stored, to be given up gradually. Cultivation and drainage aid in producing a rush of water to the streams after rains, which is followed by a period of very low flow in a dry season. The villages in time become cities, drawing their' water supply from, and discharging their sewage into, the near-by stream. This source of pollution, in connection with the occasional very low stream flow and consequent slight dilution, has been the cause of great commercial loss, of widespread disease, and of death.

IRR 113-05-2 


\section{POLLUTION BY TRADE WASTE.}

But city sewage is not the only source of stream pollution, for many industries discharge large quantities of refuse, called "trade waste," the presence of which in sewers and streams is very objectionable from a sanitary point of view.

On the continent of Europe and in Great Britain this subject has received considerable attention. The English rivers pollution act of 1876 treats the matter at considerable length. and gives city authorities power to require the adoption of remedial measures by offending factories. In the United States the necessity for legislation restricting pollution by trade waste has only recently arisen. Among the States that have already acted upon this question Massachusetts stands first.

The waste from industries is divisible into three classes-animal, vegetable, and mineral refuse, though many factories discharge two and even all three kinds.

In the first class of waste is included that from abattoirs, packing houses, tanneries, and woolen mills, which discharge large quantities of animal tissue and oil. The decomposition of this matter may be slow, and if deposited on flats it causes unpleasant odors and attracts rermin. If afloat in such quantities that the dilution is not sufficient, the water is dangerous for house use, and even cattle refuse to drink it.

To the second class belong the quantities of vegetable matter which escape from distilleries and from paper, wood-pulp, and strawboard mills-matter for which no present economical use has been found.

To the third class belong the wastes from oil refineries and gas works, which run off mineral oils and heavy tars. When discharged into eity sewer's these have proved very objectionable, and when discharged into sluggish streams they lodge on shoals and flats with the rise and fall of the water level, coating and killing vegetation, causing unpleasant odors, and fouling the water for dairying and other purposes. Tin-plate and rod mills and galvanizing and plating works discharge large quantities of chemical waste, such as dilute sulphuric or hydrochloric acid, copper sulphate, and sulphate and chloride of iron.

Among other local industries that produce serious nuisance in their vicinity are soap factories, factories using the Solvay ammonia soda process, and white lead, paint, varnish, and starch factories. Certain mineral waters used for curative and bathing purposes and the drainage from mines may also be offensive, but these are not usually amenable to pollution laws. In England they are specifically excluded in the rivers pollution act of 1876 . In Pennsylvania the higher courts have passed upon a case involving mine drainage, and the operators were allowed to continue the natural drainage of the mine.

The effect of wastes upon the condition of the stream depends on the relative volumes of stream and of waste, the strength and character of the polluting material, and the proximity of other industries or of 
cities requiring pure water and of agricultural lands and residents who might declare a nuisance. It is clear, then, that no general rules can be laid down, but that each aase of pollution must be decided on its own merits.

The addition of quantities of organic matter to a stream is highly objectionable, as it furnishes food for the rapid multiplication of disease bacteria which may be present, and it may cause a nuisance by slow decomposition by deposit upon shoals, tidal shores, and flats. Besides rendering the water impotable, abnormal amounts of organic matter cause serious damage to many purifying industries, to sugar factories, meat-packing houses, and canneries. The discharge of mineral waste, unless very highly diluted, hinder's the natural purification of the stream, and alds substances that oxidize slowly. This waste kills fish and makes the water distasteful, foul smelling, and dangerous even, to cattle, thus interfering with important agricultural interests and increasing the menace to human life.

\section{MANUFACTURE OF STRAWBOAIR.}

This report is confined to a careful study of the process of manufacture of strawboard (or pasteboard, as it is commonly called), to the chatracter of the refuse, the nature of the pollution, the damage produced, and the possible means of preventing the pollution.

The principal factories of strawboard in the United States are confined to a comparatively small area. In the report of the United States census for 1900 5! factories are recorded as making strawboard. From 157,534 tons of raw material they produced a finished product valued at $\$ 3,187,342$. Indiana led with 70,081 tons of board, worth $\$ 1,350,636$. Ohio ranks second, with 40,531 tons, worth $\$ 800,038$, and Illinois is third, with 20,100 tons, valued at $\$ 382,454$. New York, Maryland, and Michigan rank next in order. The first three mentioned make 83 per cent of the board produced in the United States, and Indiana alone produces nearly 50 per cent of the total. The straw used in Indiana cost about $\$ 3.90$ per ton, and the finished product was worth about $\$ 19$ per ton.

The strawboard industry does not. of course, include the manufacture of wood pulp, sulphite fiber, or jute.

\section{COMPOSITION OF STRAW.}

Strawboard is manufactured from rye, wheat, and oat straw. In England a special straw, known as esparto grass, is used in making paper. Rye and wheat straws are preferred, as they yield the largent per cent of collulose - the basis of all vegetable fiber. The chemical formula for cellulose is $1 /\left(C_{60} \mathrm{II}_{10} \mathrm{O}_{n}\right)$. The composition of various straws as given by Müller, "a German authority, is as follows: 
Table 1.-Composition of strans.

\begin{tabular}{|c|c|c|c|c|c|}
\hline . & $\begin{array}{c}\text { winter } \\
\text { rye. }\end{array}$ & $\begin{array}{l}\text { Winter } \\
\text { wheat. }\end{array}$ & $\begin{array}{l}\text { Summer } \\
\text { barley. }\end{array}$ & $\begin{array}{l}\text { Winter } \\
\text { barley. }\end{array}$ & Oats. \\
\hline & Per cent. & Per cent. & Per cent. & Per cent. & Per cent. \\
\hline Water.... & 14.3 & 14.3 & 14.3 & 14.3 & 14.3 \\
\hline Organic constituents. . & 82.5 & 80.2 & 79.7 & 80.2 & 80.7 \\
\hline Ash & 3.2 & 5.5 & $\ldots$ & 5.5 & 5.0 \\
\hline Cellulose ... . . & 54.0 & 48.0 & 43.0 & 48.4 & 40.0 \\
\hline
\end{tabular}

James Beveredge, of Northfleet Paper Mills, Kent, England, gives" the following results of analyses of straws:

TABLE 2.-Comproition of strans.

\begin{tabular}{|c|c|c|c|c|c|}
\hline & $\begin{array}{l}\text { Zealund } \\
\text { wheat. }\end{array}$ & $\begin{array}{l}\text { Dutch } \\
\text { wheat. }\end{array}$ & $\begin{array}{l}\text { Duteh } \\
\text { oats. }\end{array}$ & $\begin{array}{l}\text { Dutch } \\
\text { rye. }\end{array}$ & $\begin{array}{l}\text { Dutch } \\
\text { barley. }\end{array}$ \\
\hline Water .... & $\begin{array}{r}\text { Per ecut. } \\
8.2\end{array}$ & $\begin{array}{r}\text { Per cent. } \\
12.5\end{array}$ & $\begin{array}{r}\text { Per cent } \\
11.2\end{array}$ & $\begin{array}{r}\text { Perent. } \\
7.8\end{array}$ & $\begin{array}{r}\text { Per cent. } \\
11.0\end{array}$ \\
\hline Organic constituents. & 44.2 & 43.6 & 46.0 & 49.3 & 47.7 \\
\hline Ash. & 10.0 & 7.5 & 5.5 & 1.8 & 7.2 \\
\hline Cellulose & 37.6 & 36.4 & 37.3 & 41.3 & $3+.1$ \\
\hline
\end{tabular}

In table 1 the organic constituents include cellulose; in table 2 they do not. In the latter the cellulose is unbleached.

Remsen gires the following percentages of cellulose, the straws being in the air-dry state. Rye straw, 54; wheat straw, 48; oat straw, 40 . The differences appearing in the above tables are due to differences in the definition of cellulose, in the dryness of the materials, and in the various methods of separation employed. The order of the commercial rating of straws, as given by the strawboard companies, is as follows: (1) rye, (2) winter wheat, (3) spring wheat, and ( $t$ ) oat. There is generally reckoned a loss of about 40 per cent by weight from the dry straw to the finished board, the latter containing from 5 to 8 per cent of moisture. Various factors enter into the percentage of loss. Straw purchased at harvest time contains a larger percentage of moisture than it contains some months later. The loss of weight from harvest to Christmas time amounts to almost 25 per cent, says an authority in the eJournal of the Society of Chemical Industry. ${ }^{b}$ Straw grown on light, sandy soils has a much lower specific gravity than that grown on heavy clay or mixed soils. Differences are also caused by weather conditions at harvest time. A wet straw anses greater loss 


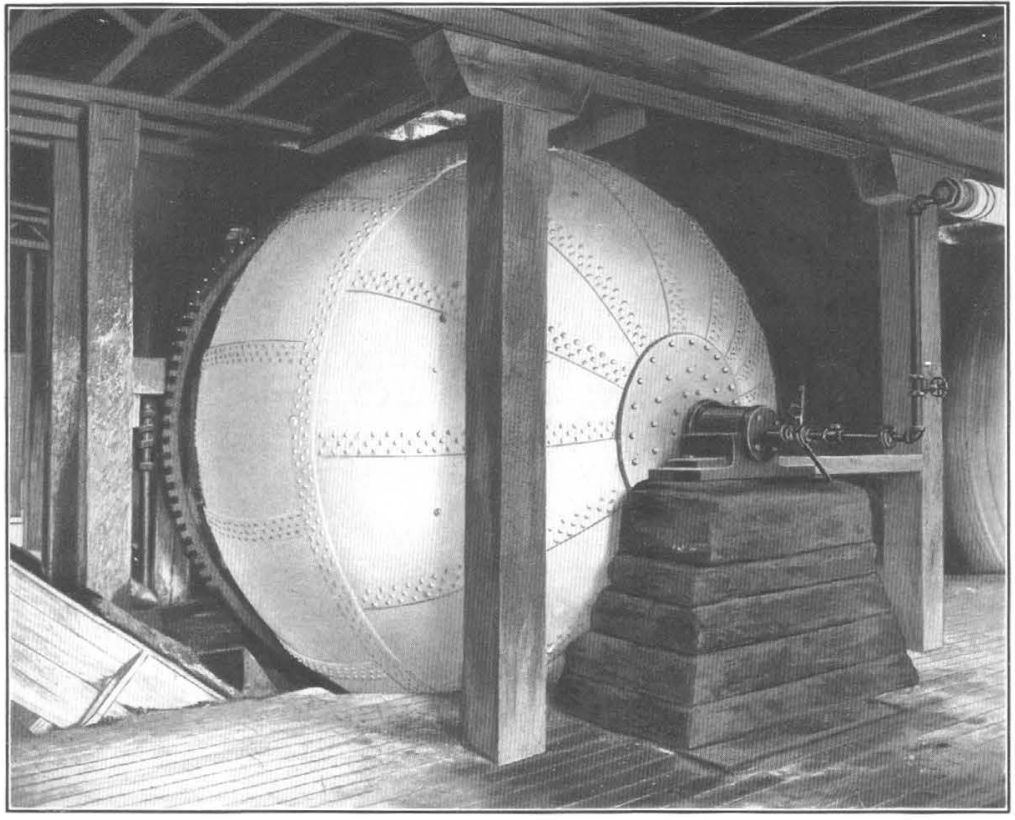

A. STRAWBOARD ROTARIES.

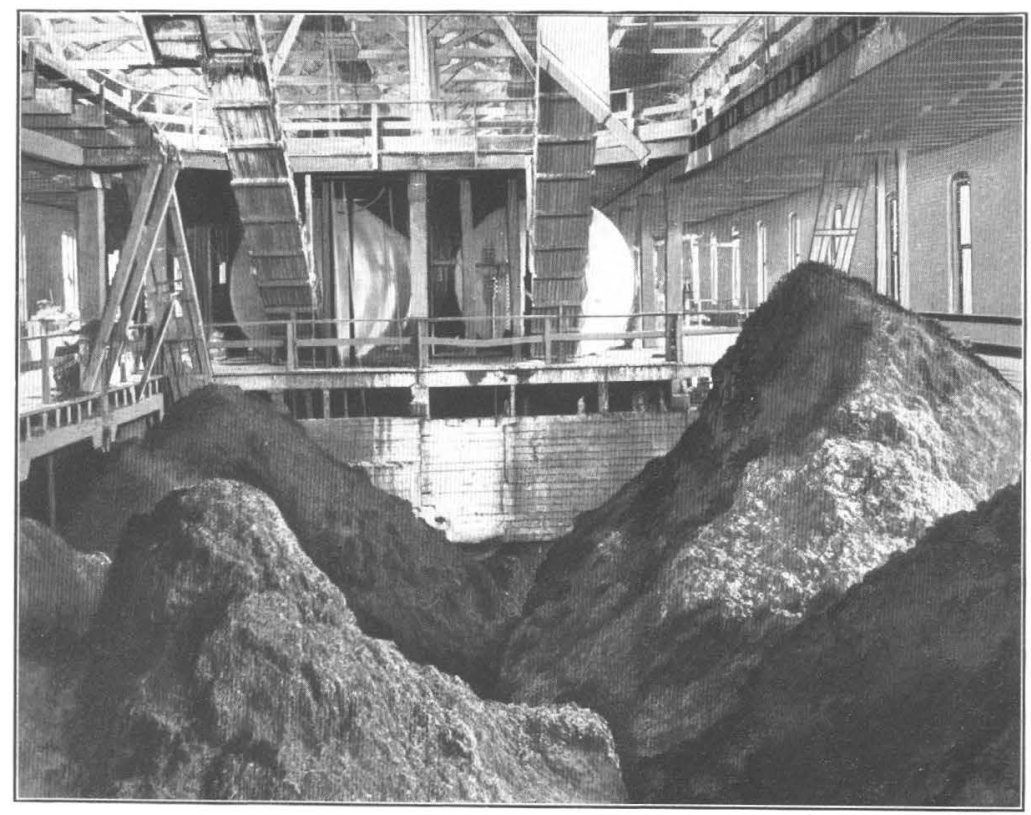

B. ROTARIES AND STOCK PILES. 
and makes a poorer quality of board. The driest material comes from that in the lofts of harns, while straw from stacks is ustally damp. It is stated that baled straw is more moist than loose straw.

Of the to per cent of cellulowe in wheat straw, about 30 per cent is sared by present means of manufacture of strawboard. The machinery and methods employed have not changed materially for many year's, and there seems to be little prospect of greater economy heing practiced. The reasons for this are discussed later in this paper.

\section{STEAMING IN ROTARIES.}

The process employed in the United States is as follows:

The straw is first subjected to a cooking process by steam and lime. A large ellipsoidal rotating steel boiler called a "rotary," shown in Pl. I, A, is filled with straw, which is then cooked down with steam, then again filled and cooked down until the rotary boiler has been completely filled. The process of filling a rotary occupies from six to twelve hours. The tinal charge consists of about 6 tons of straw and 30 bushels, or 2,100 pounds, of lime in the form of milk. This mixture is then rotated and cooked under 40 pounds of steam pressure for twelve hours. Pl. I, $A$, shows the steam line extending through one of the trunnions and the worm gear which rotates the cylinder. This apparently severe chemical and mechanical action results in a rapid softening of the woody fiber and in the reduction of the straw to a darkyellow, pulpy mass. This "stock," as it is called, is stacked in piles 10 to 15 feet high to drain. Concerning the action which takes place in the rotaries, the Journal of the Society of Chemical Industry says:"

The chemical action of the milk of lime on the encrusting materials surrounding the straw fiber is not a vigorous one. These encrusting materials are not completely, nor incleed to a great extent, separated from the cellulose. The mineral matter remains in the product practically untouched, and if any less quantity than that corresponding to the percentage in the original straw operated upon exists in the prepared $p u l p$, it is due rather to the washing after digestion than to any solvent action of the milk of lime. Milk of lime under certain conditions has a bleaching artion upon the straw. It neutralizes the organic acids usually found when fibrous plants are heated for any length of time in the presence of water.

The yield of pulp at this point will be from 75 to 80 per cent of the weight of the original material.

Pl. I, $B$, shows the rotaries, charged from the floor above, and the elevators that carry the stock from the rotaries and dump it in the piles shown in the foreground. At the extreme left is an endless-chain elevator which carries the stock to the beater room.

The material is allowed to stand in these piles for twenty-four hours or more to drain. After it is thus drained it contains about 50 per cent of water and from 6 to 7 per cent of lime. This is equiralent to from 12 to $1 \pm$ per cent of lime in the dry straw. Since the original charge 
of lime and straw was in the proportion of 2,100 pounds of lime to 14,100 pounds of straw and lime, or about 14 per cent lime, practically none of the latter has drained out with the condensed steam. This drainage from the stock piles forms hut a small part of the waste sewage. It is straw colored and very turbid, carrying a small quantity of fiber broken fine in the rotaries.

\section{WASHING.}

This process is much more drastic, and it is here that the great volume of waste is produced.

The stock is run through washing machines for the purpose of removing the lime. A row of washers in operation is shown in Pl. II, $A$. At the left is the chute from the conveyor above, down which the stock is fed. To the right of the chute are the water pipes. The washing machine consists of an oval channel about 3 feet wide, around which the stock travels, being supplied with copious volumes of water. Across this channel is placed a cylinder, 42 inches in diameter and 42 inches long, having longitudinal ribs or flanges about three-fourths of an inch square in section and three-fourths of an inch apart. Meshing with this, like the teeth of geared wheels, is an idler, below, of similar size and form. These wheels, revolving, lift the water and straw to a level several inches higher than that in the oval channel, whence it flows by gravity halfway around its course to a point where it meets a revolving brass screen of fine mesh, through which a part of the water escapes, carry ing with it the finer particles of tiber and free lime. The remaining straw, with additional rolumes of fresh water, now passes many times through the rolls, which further mash and break the fiber, and around to the screen, where more straw, lime, and water escape. The total waste is enormous. It now takes about 40,000 gallons of water to wash 1 ton of straw. About 3.200 pounds of straw and 560 pounds of lime are required to make 2,000 pounds of board. A small amount of lime remains in the board; hence 1.200 pounds of straw and about 500 pounds of lime are washed out by the 40,000 gallons of water. An idea of the volume of waste may be conveyed by giving the capacity of an average mill. Such a plant uses 50 tons of straw and nearly 10 tons of lime during every twenty-four hours. From 1,000,000 to 2,000,000 gallons of water are employed in the rotaries, washers, and vats. This volume of water carries away with it about 19 tons of the straw and practically all of the 10 tons of lime each twenty-four hours.

\section{DRYING.}

After the washing process the straw, with a considerable volume of water, is led to a train of rolls, consisting of three parts-first, the wet end; second, the hot rolls; third, the trimming and cutting machine. As it comes from the washers the material is run into vats, 


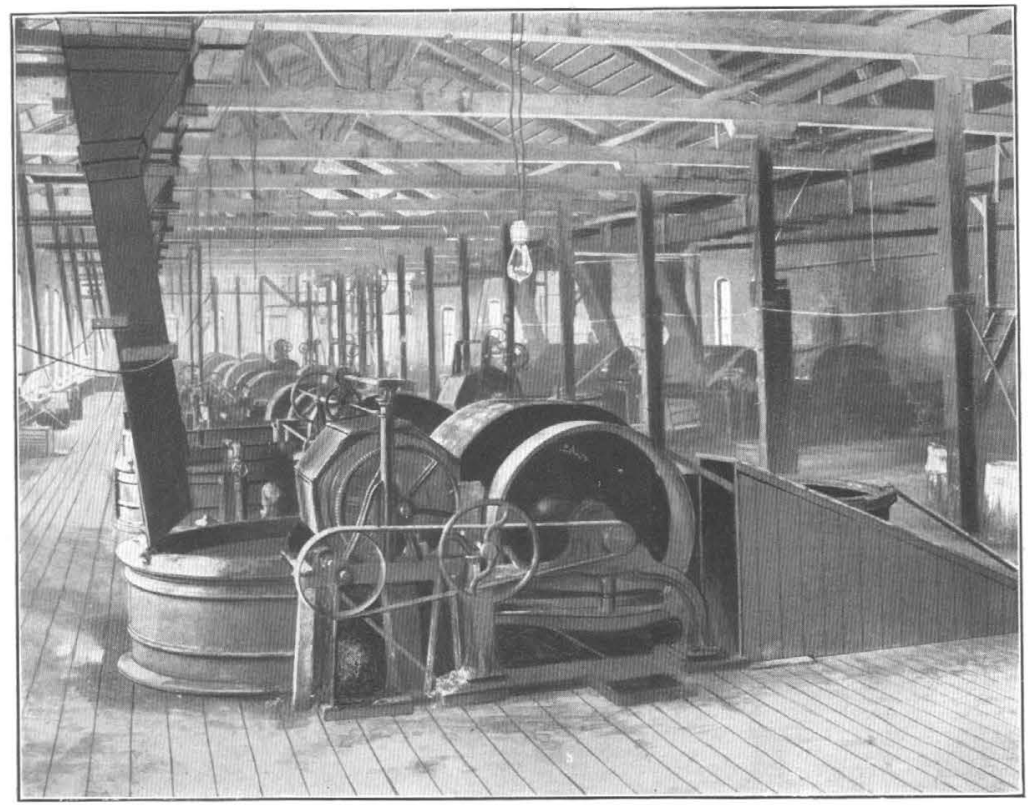

A. PULP WASHERS.

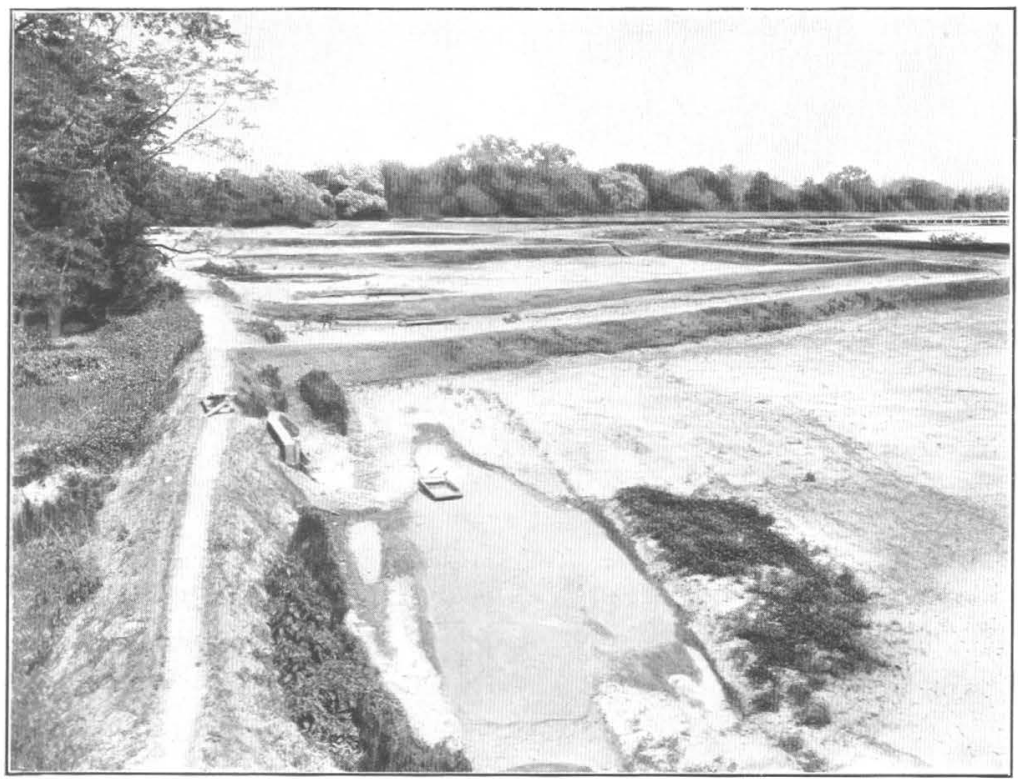

B. SETTLING BASINS. 
where it is mixed with large quantities of water and passed over hollow cylinders having fine wire-cloth faces, which allow the water to escape, leaving the fiber on the surface of the cylinder. The fiber is then taken by woolen felts, which are pressed down on the surface of the cylinder. This makes a wel of paper on the felt. The pulp, which is now about one-third straw and two-thirds water, travels up and down, over and under a double train of hot rolls, heated by steam that is carried in through hollow bearings. As the pulp passes on through the train it is constantly pressed and dried, until finally it is separated from its cloth support and goes to the trimming machine, where it is eut into sheets of proper size. It now contains about 10 per cent of water and a small quantity of lime. The board is manufactured in many thicknesses and weights. Just before it is trimmed it may be coated on one or both sides with a thin paper facing or finish.

\section{METHODS OF DISPOSAI OF WASTE.}

The waste liquors from the rotaries and washers, and that from the vats where it is not used over again in the washers, are run together and discharged into a trough or ditch, leading in some cases to a neighboring stream. The effect of these wastes upon the stream depends upon its character and volume. As many Indiana rivers flow over limestone beds, their water is hard, carrying 15 to 20 grains of lime per gallon. But the waste liquor from a strawboard mill contained in one case a minimum of 66 grains per gallon (an amount which has recently been doubled by a decrease in the quantity of water used), and in some cases, where wash water is not plentiful, the quantity of lime reaches 200 or more grains per gallon. In order to reduce the quantity of lime to 40 grains per gallon the minimum stream flow would need to be about ten times the volume of water employed in the process. This would require a stream that discharged, in time of drought, from 10 to 20 million gallons in twenty-four hours. This limits the number of streams upon which such mills can be operated in the present manner without nuisance, to a few rivers in each State.

On account of the clearing of forests, artificial drainage, and irregularities of rainfall the flow of Indiana tributaries becomes extremely low in the late summer and fall. Some, indeed, cease to be more than isolated ponds, the water seeping through the gravel beds. Under these circumstances, if not under normal conditions, the discharge of sludge into a stream produces results that demand very serious consideration. The straw waste, when deposited on flats from which the water has receded, decomposes very slowly, its decay being in part retarded by the presence of lime and silica. Remsen says that as much as 73 per cent of the ash of wheat straw is silica. As the analyses given in table 4 (p. 27) show, the quantity of ammonia present 
in the waste is very large, and this is undoubtedly the principal cause of the very slow decomposition.

At some places the solid part of the waste has been heaped on large tracts of land. In these cases the stench produced has been carried by the wind for a considerable distance, causing a nuisance.

Mr. Sweeney, commissioner for fisheries and game for Indiana, in his biennial report for 1901 and 1902, speaking of the conditions which tend to destroy fish, says, on page 11:

Greater than all other artificial means is the pollution of our streams with the refuse from strawboard mills, oil wells, and pulp mills. This refuse covers the spawning beds and prevents the eggs from hatching, while it penetrates the gills of the living fish and kills or drives them from the streams.

The quantity of lime would in some cases be such as to kill the fish if the straw did not. Game fish are not to be found in polluted waters. Thus the interests of the State enter into the question of stream pollution by strawboard mills.

In other cases the method of disposal has been modified by running the waste into a series of beds scooped out of a gravel bottom land. Here the straw and lime slowly settle, the water filtering through the subsoil and finding its way to the neighboring creek. But the great quantity of straw waste soon clogs such natural filters as have been tried. High water is depended on to wash the refuse out of the beds, whence it is deposited on other lands below; so that the method is only a makeshift.

What a carefully constructed settling and filtering plant may accomplish has not yet been determined. During the summer of 1903 the American Strawboard Company built at one of its factories a series of basins, shown in Pl. II, B, Pl. III, and fig. 1. Basins Nos. 1 to 5, fig. 1, average an acre each, while No. 6 is about 2 acres in area. Levees from 4 to 6 feet high were built, so that the basins could be filled to a depth of about 5 feet. From the old ditch which is shown in fig. 1 a spout was constructed to conduct the waste into basin No. 1 . From this basin it flows diagonally to a weir at the opposite corner, where it enters basin No. 2. The flow is diagonally across each basin to the next in order through the series, to No. 5 or No. 6 . From basin No. 5 a gate leads to filter No. 1 , and from basin No. 6 a similar gate leads to filter No. 2. These filters have lines of 8 -inch tile laid 25 feet apart and covered with 2 feet of gravel. The underdrains lead to the open ditch between the two filters. Each basin has a gate leading to the river, so that the waste can be run through any number of settling basins and then into the river or through the filters. The waste was turned into basin No. 1 in the early summer. When it had filled, the overflow ran into basin No. 2, and so on, basin No. 6 being filled in late summer. 


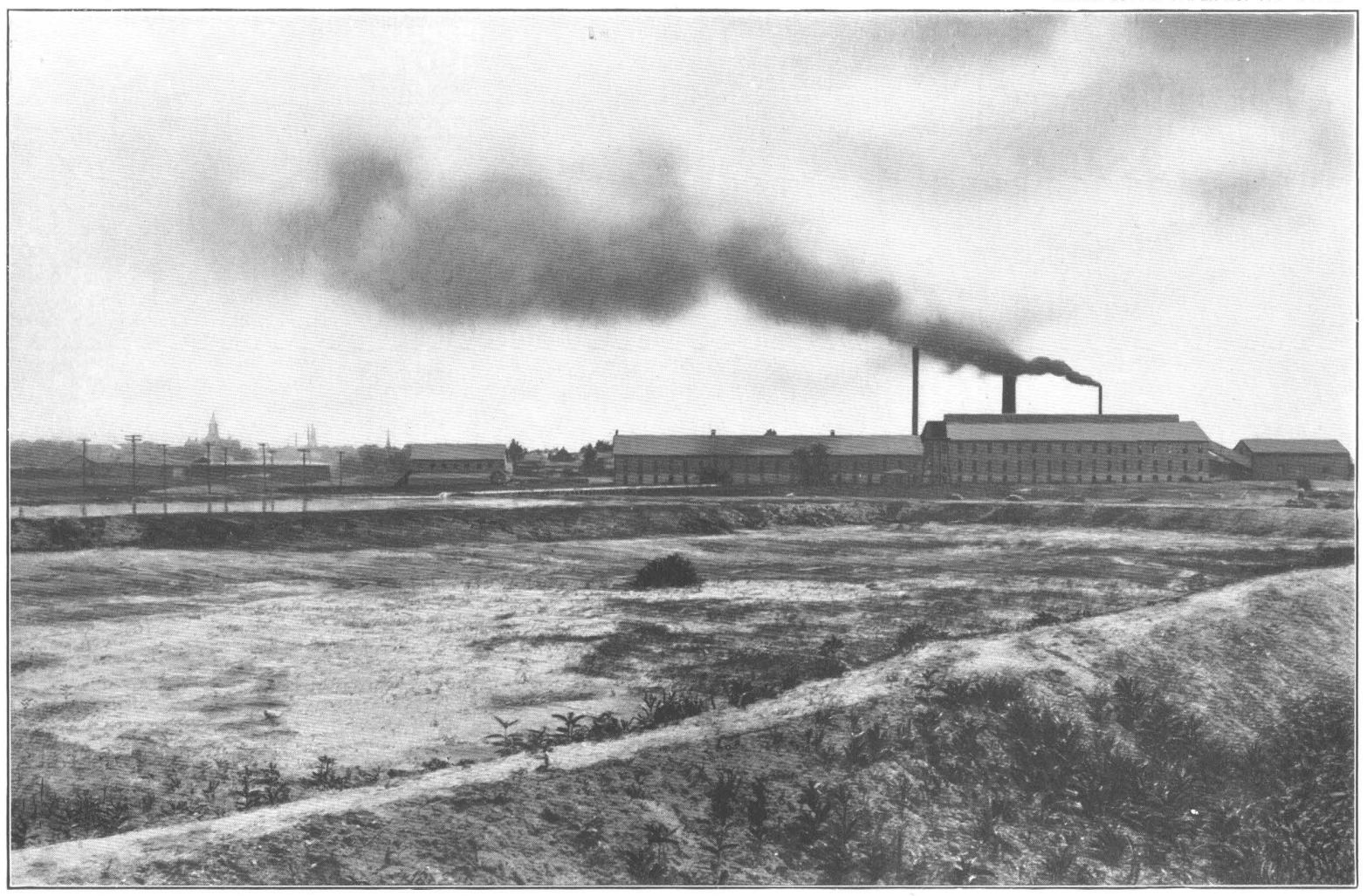


It seems inevitable that in time there will be a large deposit of straw and lime, which will have to be scraped off the basins and filters and carted away. Seepage through the walls and bottoms of the basins will decrease and the filters will clog until the efficiency has reached an unsatisfactory point. The period of time which will elapse before

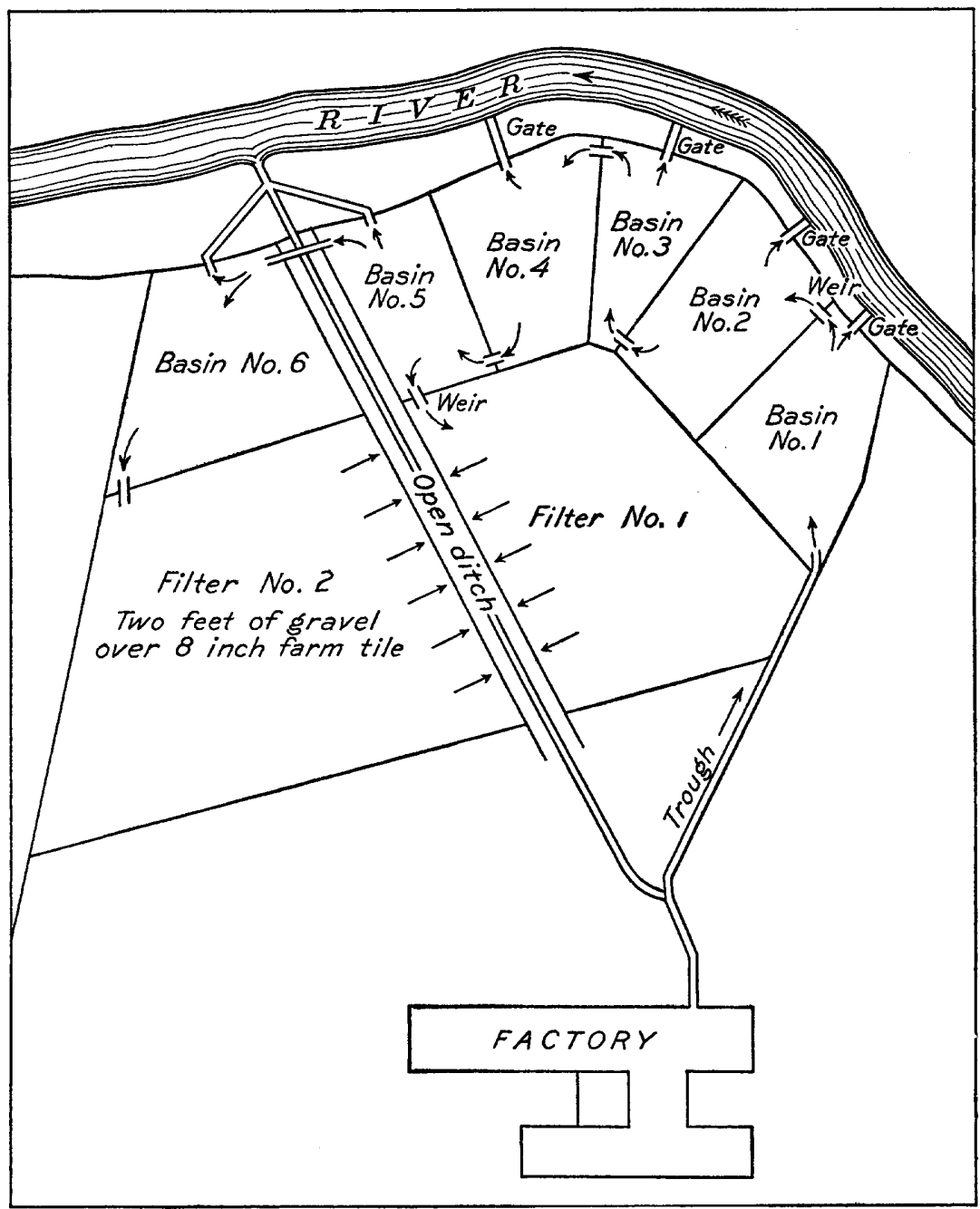

FIG. 1.-Plan of strawboard settling basin.

this condition arises and the effectiveness of months of sedimentation, with or without filtration, will not be known until a season has passed.

At one of its plants the American Strawboard Company used a trough-shaped device for separating the fine straw from the waste water. A vat 16 feet long was constructed, the end view of which 
was practically an equilateral triangle. The waste as it came from one of the washers was discharged into this vat, so that the water started downward, then turned upward through a screen, leaving the straw to continue downward. The screens clogged in the course of time and had to be cleaned by hand. The vat held about 7,000 gallons and treated 70,000 gallons in twenty-four hours.

As the waste passed from the washers to the vat the analysis was as indicated in the first column, and the analysis as the water came from the vat is recorded in the second column.

Analyses of strawboard waste before and after passing from washers to vat.

[In parts per 100,000.]

\begin{tabular}{|c|c|c|}
\hline & Before. & After. \\
\hline \multicolumn{3}{|l|}{ Suspended matter: } \\
\hline Organic matter... & 565.7 & 188.6 \\
\hline 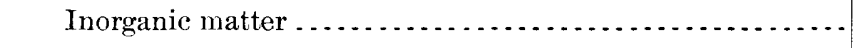 & 393.1 & 123.3 \\
\hline Total residue. . .... & 958.8 & 312.5 \\
\hline \multicolumn{3}{|l|}{ Total solids: } \\
\hline Organic matter ....................... & $1,294.5$ & 528.5 \\
\hline Inorganic matter ............... & 661.8 & 244.3 \\
\hline Total residue.... & $1,956.3$ & 772.8 \\
\hline Calcium & 510.5 & 204.8 \\
\hline
\end{tabular}

It will be seen that the vat removes about 66 per cent of the suspended matter. The latter is, however, abnormally high, and the effluent still contains 312.5 parts per 100,000 --five to ten times what it should before passing to a stream. Increasing the size of vat and decreasing the rate of flow, with some changes of design in order to emphasize the upward-flow principle, might lead to a design which would be sufficient where the stream flow and dilution were high.

No bacterial treatment such as is employed in the purification of sewage will avail in this case, as the treatment with lime and steam in the rotaries destroys all the bacteria present. A considerable period must elapse for the cultivation of such organisms.

\section{EXPERIMEN'TS ON DISPOSAL OF WASTE.}

To determine the possibility of other and more efficient methods of disposal than those just outlined, the author was appointed to take charge of a series of experiments on strawboard waste and to report their results to the United States Geological Survey. His instructions were to study the process of manufacture, analyze the waste liquor, and find the efficiency and cost of various methods of disposal, in order 
that some recommendation might be made to the authorities or to the manufacturers when circumstances should demand a change in the method of disposal.

The expense is a very important item, as it is easy to find a method of treatment by which the waste can be purified, but the cost would prevent the operation of the mill. Other methods will clarify the waste, but leave the water extremely hard, thus accomplishing but half the purpose. Theoretically, the liquid which eventually flows into the stream ought not to be harder than the normal stream-a condition extremely difficult to fulfill by commercial methods. Likewise, the total solids should not be above an average amount contained in natural waters.

\section{METHODS OF PURIFICATION.}

There are three general methods of treatment for the purification of polluted water-sedimentation, filtration, and chemical precipitation.

\section{SEDIMENTATION.}

This process consists of letting the liquid stand for a period of time long enough to allow the matter held in suspension to settle to the bottom. There is no chemical action involved, but since organic as well as inorganic matter may be settled, future chemical changes are possible. The hardness or acidity will not be changed. The rapidity and efficiency of the process depend on the specific gravity of the suspended matter. Silt will settle quickly, and this process is frequently used to remove such objectionable material from water supplies.

In the case of strawboard wastes, the particles of straw are so fine and the specific gravity is so slightly above unity that the downward motion is very slow. A jar 10 inches high will settle about 10 per cent of its solid matter in twenty-four hours. In twenty-four hours more the change is very slight. At the end of twenty-four hours, color, turbidity, odor, and taste are about the same as before such treatment. The storage capacity required for twenty-four hours' settling would be twice the capacity of the mill. To settle forty-eight hours reservoirs that would contain three times the volume of refuse would be required, and so on. From 2,000,000 to 4,000,000 gallons' storage would be needed for such treatment.

Even with still longer periods of sedimentation the hardness would remain practically unchanged, as the only lime precipitated would be due to the $\mathrm{CO}_{2}$ absorbed from the atmosphere.

\section{FILTRATION.}

The process next to be described, and one now very frequently used in the purification of water supplies and of sewage, is filtration. The water is allowed to pass slowly through a bed of charcoal, coke, furnace 
slag, or sand. The process is partly a screening one, but under proper conditions a very efficient bacterial action takes place, in which the healthful bacteria assist in reducing the organic matter to its constitnent elements. Bacillus coli-communis - the biological index of sewage pollution-disappears, and not only suspended matter but the amount of chlorine is reduced, and the number of bacteria per cubic centimeter is decreased by from 95 to 99 per cent of the number present in untreated water.

There are two kinds of filters, mechanical and slow sand filters. In the former the rate of flow is higher and frequent cleansing is necessary, while in the sand bed the rate of filtration is much less and the filter purifies itself in part while resting or while in action. If the surface becomes clogged, occasional rakings are necessary in order to remove the clogged surface and restore it to its normal state.

\section{CHEMICAL PRECIPITATION.}

In this process the liquid is treated with a previously determined quantity of some chemical which will cause a reaction involving the production of a solid in the form of grains or flakes. As the precipitant has a specific gravity greater than water, it falls and drags down with it other solids. The rapidity of its action depends on the proper proportioning and mixing of the agents employed and on the weight of the particles and their size. A flocculent, heavy precipitate rapidly carries down with it a large proportion of the organic and inorganic matter that has been held in suspension.

Such processes are usually continuous; the fluid to be treated and the reagent are automatically mixed and fed in at the bottom of the tank, the current being upward. The purified liquid is taken from the top of the tank and the precipitated sludge is drawn from the bottom. Certain limitations have been found in the successful operation of the upward-flow principle. Hàns Benedikt, in Die Abwasser der Fabriker (Trade Waste), states that the normal downward velocity of suspended matter in still water must be at least 2 millimeters per minute. He also says:

If it be desired to perfectly clarify by deposition, on the upward continuous flow principle, water which is naturally charged with suspended matter, or by the addition of precipitants, a transverse section of more than $0.002 \times 60=8.33$ square meters is required to obtain 1 cubic meter per hour of clear water, in order that the upward velocity of the water may be less than the downward velocity of the particles.

The chemicals most frequently employed in water purification are alum, sulphate of iron, lime, copperas, and combinations of these. It is very important that the proportion of coagulant be aiways correct, else either the action is not completed or unnecessary waste results from overcharging. 
Coagulants Used.

The series of investigations was begun by using small quantities of waste liquor-from 50 to 100 cubic centimeters-and trying the effects of various chemicals in different quantities.

ALUM.

The effect of alum was rapid, showing that it is a very satisfactory coagulant. The liquid was left slightly turbid and with some odor. The hardness was not affected. The chemical action was as follows:

$$
3 \mathrm{CaO}_{2} \mathrm{H}_{2}+\mathrm{Al}_{2}\left(\mathrm{SO}_{4}\right)_{3}+\mathrm{K}_{2} \mathrm{SO}_{4}+24 \mathrm{H}_{2} \mathrm{O}=3 \mathrm{CaSO}_{4}+\mathrm{Al}_{2} \mathrm{O}_{6} \mathrm{H}_{6}+\mathrm{K}_{2} \mathrm{SO}_{4}+24 \mathrm{H}_{2} \mathrm{O} \text {. }
$$

The quantity of alum is to the quantity of calcium oxide as 948 is to 168 . About 112,000 pounds of alum is needed daily to treat waste water containing 19,800 pounds of lime and straw.

The usual process for producing alum, or sulphate of alumina, is to treat the mineral bauxite with sulphuric acid. In England some mills have found it very cheap to make the necessary quantity in their own plant. The resulting cake, according to Naylor in Trade Waste, page 21 , is 36 per cent sulphate. The cost is $\$ 4.70$ per short ton of product or $\$ 13.40$ per ton of pure sulphate.

In the United States, on account of the excessive cost of bauxite and sulphuric acid, commercial sulphate 57 per cent pure will cost about $\$ 16$ per ton delivered, or $\$ 28$ per ton of pure sulphate delivered. The daily expense for 56 tons would be $\$ 1,568$. This cost of partial purification, omitting other items, would absolutely prevent the operation of any mill consuming 50 tons of straw a day.

Not only is the expense objectionable, but the quantity of lime in the water, making the water permanently hard, must be reduced, else the process is not satisfactory.

SULPHATE OF IRON.

Ferrous sulphate is used in water-purifying processes, giving a dark-brown precipitate. The action is rapid and the clarification satisfactory. The use of one atom of iron for each molecule of calcium oxide present in the water produces the following reaction:

$$
\mathrm{CaO}_{2} \mathrm{H}_{2}+\mathrm{FeSO}_{4}=\mathrm{CaSO}_{4}+\mathrm{FeO}_{2} \mathrm{H}_{2} \text {. }
$$

When the proper amount of ferrous sulphate is added to 100 cubic centimeters of strawboard liquor the precipitation is almost instantaneous, and in five minutes the solid portion lies at the bottom in a brownish cake. The liquid above is very clear, having only a slight greenish tinge.

Since a daily output of 19,800 pounds of lime is assumed as a working basis, in order to make the comparison of cost apply to a particular mill 19,800 pounds of iron would be needed and 34,700 pounds of sulphuric acid. 
The proper process would be to treat scrap iron with sulphuric acid in a reservoir. The expense would be--

19,800 pounds iron, at $\$ 7.50$ per ton of 2,000 pounds $\ldots \ldots \ldots \ldots \ldots \ldots \ldots \ldots \ldots$

34,700 pounds sulphuric acid $\left(\mathrm{H}_{2} \mathrm{SO}_{4}\right)$, at $\$ 12$ per ton $\ldots \ldots \ldots \ldots \ldots \ldots \ldots \ldots \ldots . .208$

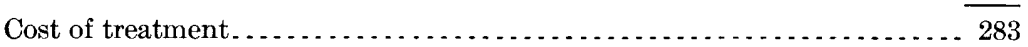

The same objections apply to the use of sulphate of iron as to alum. The expense is too great, and lime remains in the form of $\mathrm{CaSO}_{4}$, which leaves the permanent hardness very high.

Instead of using sulphate of iron as above produced, the crude sulphate, copperas, a by-product of certain processes, can be employed. It is 25.9 per cent ferrous oxide and 28.7 per cent sulphur trioxide $\left(\mathrm{SO}_{3}\right)$. Roughly, 4 tons of copperas, at $\$ 9$ per ton delivered, would treat 1 ton of lime. For 19,800 pounds of lime nearly to tons of copperas would be required, at a cost of $\$ 360$ daily. While this process would be more economical than the use of sulphate of iron, when all items of expense are figured, still the cost is excessive and the process impossible as a general treatment for all the waste from a strawboard mill.

LIME.

Lime is one of the most common coagulants used in clarifying drinking waters. The usual stream carries a small amount of carbon dioxide, which combines with from 5 to 10 grains of calcium oxide to form calcium carbonate, which precipitates in tine, white particles, dragging down such organic and inorganic solids as may be held in suspension.

This process fails in treating strawboard refuse because the liquor is already many times overcharged with lime, by a part of which the little $\mathrm{CO}_{2}$ that was in the water has been greedily used and the remaining lime is seeking more. The addition of milk of lime does not produce perceptible action.

\section{CARBON DIOXIDE.}

The facts above mentioned led at once to the conclusion that carbon dioxide must be fed to the waste liquor. On applying the computed amount of $\mathrm{CO}_{2}$, it was found that but little precipitation actually occurred. The reason for this may be stated as follows: (1) $\mathrm{CaO}+$ $\mathrm{H}_{2} \mathrm{O}=\mathrm{CaO}_{2} \mathrm{H}_{2}$, or the lime in the waste liquor is in the form of calcium hydroxide. (2) On applying $\mathrm{CO}_{2}, \mathrm{CaO}_{2} \mathrm{H}_{2}+\mathrm{CO}_{2}=\mathrm{CaCO}_{3}+\mathrm{H}_{2} \mathrm{O}$, precipitation by $\mathrm{CO}_{2}$, occurs; but at the same time the lime is redissolved, as follows: (3) $\mathrm{CaCO}_{3}+\mathrm{H}_{2} \mathrm{O}+\mathrm{CO}_{2}=\mathrm{H}_{3} \mathrm{Ca}\left(\mathrm{CO}_{3}\right)_{2}$, making a bicarbonate of lime. No precipitation has yet occurred. But if to the double carbonate of lime we add milk of lime the following action takes place: (4) $\mathrm{H}_{2} \mathrm{Ca}\left(\mathrm{CO}_{3}\right)_{2}+\mathrm{CaO}_{2} \mathrm{H}_{2}=2 \mathrm{CaCO}_{3}+2 \mathrm{H}_{2} \mathrm{O}$. Reprecipitation now takes place, carrying down the straw and calcium. The flakes are very large and the downward velocity is exceptionally rapid. In five minutes the 
liquor has cleared at the top and in twenty minutes the process is completed.

CARBOy DIOXIDE AND MILK OF LIME.

As above indicated, it is not sufficient to apply limewater or carbon dioxide alone, but upon first saturating the liquor with $\mathrm{CO}_{2}$ and then supplying the proper amount of milk of lime the result is very satisfactory. It will be observed that not only is the straw removed, but the water comes out soft; that is, the calcium also is removed. None of the previous treatments will precipitate the lime.

It is observed that the amount of $\mathrm{CO}_{2}$ required for the previous reactions is two molecules per atom of calcium in the waste liquor.

From (4) it appears that the amount of calcium added as milk of lime equals the amount present in the waste liquor. Assuming that the finished strawboard does not contain more lime than is in the river water used, there are needed 19,800 pounds of lime as precipitant.

The following analyses, made by E. J. Macy under the direction of Prof. W. D. Collins, at Earlham College, will present the important facts in concrete form:

TaBle 3.-Residue contained in stramboard waste liquor.

[In grams per 100,000 ('nbic centimeters.]

\begin{tabular}{|c|c|c|c|}
\hline & \multirow{2}{*}{ Raw liquor. } & \multicolumn{2}{|c|}{$\begin{array}{l}\text { After precipitation with } \\
\mathrm{CO}_{2} \text { and milk of lime. }\end{array}$} \\
\hline & & $\begin{array}{l}\text { Filtered af- } \\
\text { ter settling } \\
1 \text { hour. }\end{array}$ & $\begin{array}{l}\text { Filtered af- } \\
\text { ter settling } \\
24 \text { hours. }\end{array}$ \\
\hline Total residue... & $\begin{array}{l}\text { Grams. } \\
293.66\end{array}$ & $\begin{array}{l}\text { Grams. } \\
137.59\end{array}$ & $\begin{array}{l}\text { Grams. } \\
33.325\end{array}$ \\
\hline Combustible residue.............. & 134.63 & 65.63 & 31.250 \\
\hline Absolute residue $\ldots \ldots \ldots \ldots \ldots \ldots \ldots \ldots$ & 159.03 & 71.50 & 1.800 \\
\hline
\end{tabular}

The absolute residue is a white powder, principally calcium oxide.

The above results were obtained by treating 350 cubic centimeters in a tube seven-tenths of a meter high. This form was chosen in order to approximate the depth of tank which might be employed on a larger scale. The proportions of height to cross section were not those which would be used commercially, and hence the fall of particles was hindered much more by friction against the sides of the vessel than they would have been in a larger container. After settling one hour, 53 per cent of the total solids are removed and 55 per cent of the absolute residue, principally lime. After settling twenty-four hours, 89 per cent of the total solids are removed and 98.8 per cent of the absolute residue. 


\section{EXPERIMENT STATION.}

A light structure, 8 by 12 feet in plan and 14 feet high, with three stories or platforms, was erected on the grounds of Earlham College, Richmond, Ind., for the treatment of strawboard waste in

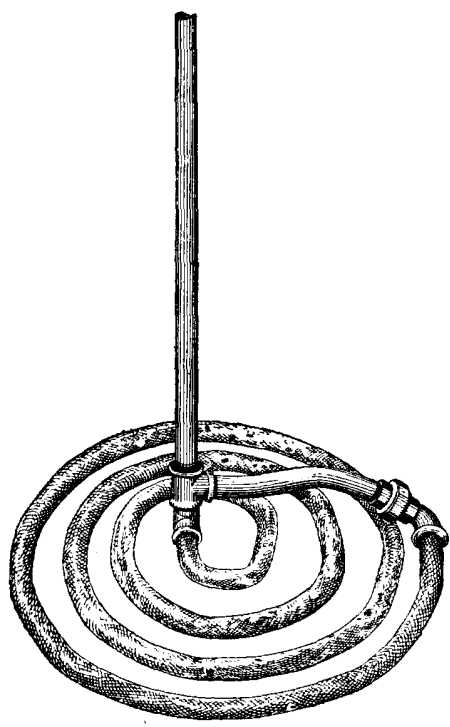

FIG. 2.-Carbon-dioxide distributor. larger quantities. The filters were on the lower platform and were provided with sewer connection. Above the platform was the barrel in which the precipitants were added to a given quantity of liquor. On the upper platform was the limewater and a tank for generating gas under sufficient pressure to force it against a head of 3 feet of water.

The gas tank consisted of a steel cylinder with a screw top closing on a gasket. $A$ valve connection was made at the upper end and a standpipe by which to add acid. The tank was charged with a quantity of limestone. Then the proper amount of hydrochloric acid was turned down on the limestone from a reservoir within the tank. The quantity of acid was made sufficient to generate and to deliver to the waste the required amount of $\mathrm{CO}_{2}$. A charge of 35 gallons of waste as fresh as could be obtained was saturated with $\mathrm{CO}_{2}$, the gas being distributed through the waste by means of holes in a coil of half-inch gas pipe placed near the bottom of the tank. (See fig. 2.) The coil could be raised or lowered, and, as was expected, the best results were obtained with the gas distributor as low as possible.

The limewater was discharged through perforated pipes, shown in fig. 3, radiating from a central vertical main. The holes were arranged in such manner as to cause a swirl of the waste, which produced a very thorough mixture.

The order of procedure was, first, to measure a certain amount of waste in the calibrated precipitation tank; second, to charge the gas generator, which delivered the proper amount of $\mathrm{CO}_{2}$ in about ten minutes, and to apply the limewater-about 5 gallons. The resulting action was immediate. A heavy cloud of large particles formed and began a descent which indicated a specific gravity much

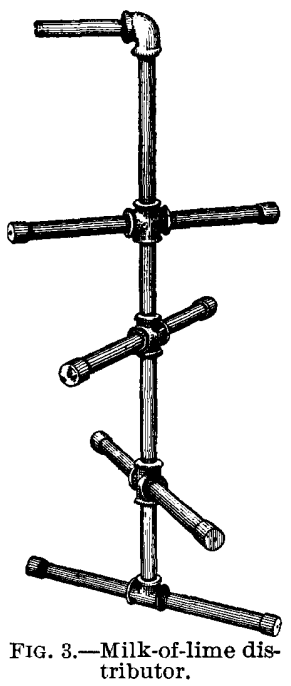
larger than unity. The surface began to clear at once, and after settling from five to thirty minutes the process of siphoning the clarified liquor onto the filter below was begun. 
The filters consisted of barrels filled with varying quantities of coarse gravel, fine gravel, and sand. These were operated at different rates, and the efficiencies were determined from analyses. Samples of the effluent and of the filtrate were taken from each barrel, and the results are recorded in table 4 (p. 27). These samples were taken when about one-half of the barrel had been treated. Five gallons of sludge were left in the bottom of the precipitation tank. This was a thick, sirup-like mass of dark-yellow straw, slightly whitened by the excess of lime that was sometimes present when a surplus of milk of lime was used.

Two molecules of carbon dioxide are required for each molecule of lime present. The strawboard company reported that $2,000,000$ gallons of water were used to carry away the 19,800 pounds of lime wasted. This is equivalent to 66 grains per gallon, or about 100 parts per 100,000 . The quantity of $\mathrm{CO}_{2}$ needed was, presumably, 200 parts per 100,000 of waste.

An amount of lime should be added equal to that present in the waste, or the total lime thrown down should be about 200 parts per 100,000. As shown in table 3 (p. 23), the absolute residue in one sample of untreated strawboard waste, taken at random, was 159.13 parts per 100,000 , showing an increase of 50 per cent in the proportion of lime. There is some variation in the quantity of lime used, depending on the quality of the straw, and a still greater range in the volume of water wasted.

A standard treatment was decided upon, in which the proportions were 200 parts of $\mathrm{CO}_{2}$ and 5 gallons of limewater (or about 150 parts of lime) to 100,000 parts of waste. The color of the solid matter thrown down showed that the precipitants were sometimes used in excess.

\section{DESCRIPTION OF EXPERIMENTS.}

SINGLE BARREL TESTS.

Tests were first made by single barrels, in the manner and with the results shown below:

\section{Barrel No. 1.}

Thirty gallons of waste.

Carbon dioxide equal to 200 parts per 100,000 .

Five gallons of limewater.

Stirred and allowed to settle thirty-five minutes.

Siphoned 30 gallons off in thirty minutes onto filter composed as follows: A barrel with 9 inches of very coarse gravel in the bottom; then 5 inches of gravel from one-fourth to 1 inch in diameter; next, 10 inches of coarse sand, and finally, on top, 7 inches of fine washed sand. 
The area of the surface of the filter was 4.50 square feet, or about one nine thousand six hundred and eightieth part of an acre.

The rate of filtration was about $13,000,000$ gallons per acre daily, which was, of course, too fast to accomplish much. Both filtrate and effluent were colored, strong in taste, and smelled of lime. No samples were taken.

\section{Barrel No. Q.}

Thirty-five gallons of strawboard waste.

Carbon dioxide.

Five gallons of limewater (milky).

Settled twenty minutes.

Siphoned 30 gallons onto filter in 1 hour and 52 minutes.

The precipitated matter, 4 inches deep, was light yellow. Free lime present. Sample after precipitation 50 per cent cleaner.

The effluent was still clearer, with bitter taste and some odor, and was still yellow color.

Filtration was at the rate of about $3,500,000$ gallons per acre daily, which removed about 16 per cent of the lime that came to it (see sample 2, table 4).

\section{Barrel No..}

Thirty-five gallons of strawboard waste.

Carbon dioxide.

Five gallons of limewater.

Fourteen minutes to charge with gas.

Settled six minutes.

Time of filtration, two hours and twenty minutes.

Rate of filtration, 2,780,000 gallons a day.

Filter, 9 inches of coarse gravel in bottom, 2 inches of fine gravel, $16 \frac{1}{2}$ inches of fine washed sand on top.

The liquor from precipitation tank showed 244.18 parts per 100,000 of lime. After filtration it showed 177.68 parts. Efficiency of filter equals 27.6 per cent. Color and taste noticeable.

$$
\text { Barrel No. } 4 .
$$

Thirty-five gallons of strawboard waste.

Carbon dioxide.

Five gallons of limewater.

Took seventeen minutes to charge with carbon dioxide.

Settled six minutes.

Time of filtration, three hours and forty-five minutes.

Rate of filtration, 1,730,000 gallons per acre daily.

Filter, 2 inches of very coarse gravel in bottom, 2 inches of gravel, then, on top, 22 inches of medium washed sand, which passed sieve of one-eighth inch mesh. 
It will be noticed in sample 4, table 4 , that the effluent from the precipitation tank contained only 85.12 parts of lime per 100,000 , or about one-third that found in the previous cases and about 53 per cent of the absolute residue in the untreated sample of table 3 . It is certain that more than 50 per cent of the absolute residue was removed by the process of precipitation. On the other hand, the filter apparently accomplished nothing. This result is probably due to lime which was carried over in the previous work and which was washed out of the filter with the present filtrate.

TABLE 4.-Amounts of calcium, free ammonia, and albuminoid ammonia contained in effuent of strawboard treated uith carbon dioxide and lime water in experiments at Earlham College, Indiana.

[In parts per $100,000$.

\begin{tabular}{|c|c|c|c|c|c|c|}
\hline & \multicolumn{2}{|c|}{ Sample No. 2.} & \multicolumn{2}{|c|}{ Sample No. 3.} & \multicolumn{2}{|c|}{ Sample No. 4.} \\
\hline & $\begin{array}{l}\text { Before fil- } \\
\text { tration. }\end{array}$ & $\begin{array}{l}\text { After filtra } \\
\text { tion. }\end{array}$ & $\begin{array}{l}\text { Before fil- } \\
\text { tration. }\end{array}$ & $\begin{array}{l}\text { After fil- } \\
\text { tration. }\end{array}$ & $\begin{array}{c}\text { Before fil- } \\
\text { tration. }\end{array}$ & $\begin{array}{l}\text { After fil- } \\
\text { tration. }\end{array}$ \\
\hline Calcium...... & 283.024 & 236.868 & & $\cdots$ & 85.12 & 89.78 \\
\hline Free ammonia .... & 1.675 & .7 & .835 & .8 & 2.50 & 3.0 \\
\hline Albuminoid ammonia ...... & 1.125 & 1. 336 & 1.0 & .7 & 1.0 & 1.15 \\
\hline
\end{tabular}

TEN-BARREL TEST.

In order to approach commercial methods as closely as seemed possible in a small experimental plant, a test of 10 barrels of strawboard waste was arranged to close the work.

First. Three barrels of waste were run through the precipitation tank, filling it and two other barrels, which served as reservoirs. The milk of lime and $\mathrm{CO}_{2}$ were fed continuously and in proportion to the rate at which the waste flowed. It was difficult to regulate the flow of the waste by valves, as the straw would choke them, thus varying the discharge. It was therefore necessary to make the rate of flow into the precipitation tank high. Automatic floats could not be used to properly proportion the waste and lime, as the volume discharged was too small to overcome the friction of such devices.

The two reservoir barrels were allowed to stand twelve hours; then samples were taken from the top of each. The first barrel was siphoned onto a coke filter, consisting of a barrel with 2 feet of fine coke breeze, the top 6 inches of which consisted of particles onefourth inch in diameter.

The second barrel was siphoned onto a sand filter baving 6 inches of fine gravel in the bottom and 24 inches of fine sand on top. The latter passed a sieve of one-eighth inch mesh.

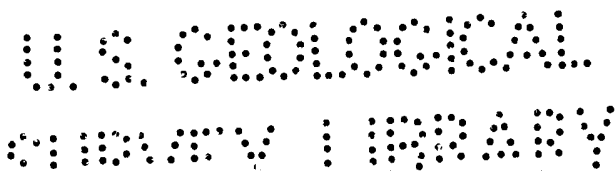


The rate of filtration was 50 gallons in twelve Lours. As the filters were approximately 0.0001 of an acre in area, the rate of filtration through the coke was 1,000,000 gallons per acre per twenty-four hours. The rate through the sand was half as rapid, or 500,000 gallons per acre daily.

Precipitation and settling in the first barrel removed 47 per cent, and in the second barrel 90 per cent, of the suspended matter. The coke filter accomplished practically nothing. The sand filter removed 25 per cent of the suspended matter reaching it, making the total removal by precipitation, twelve hours' sedimentation, and sand filtration, 92.6 per cent. The greater efficiency of the precipitation into the second barrel was due to a better adjustment of the proportions of lime and $\mathrm{CO}_{2}$ to the waste.

Second. Two reservoir barrels were again filled in order by the effluent from the precipitation tank. Each settled one hour. Then one filtered through the coke, the other through the sand, each at the rate of 50 gallons per twelve hours, or 1,000,000 gallons per acre daily. The efficiency of the precipitation and settling one hour was 20 per cent; of precipitation, settling one hour, and sand filtration, 90 per cent.

Third. In another and similar case the efficiency of precipitation and settling thirty minutes was 75 per cent; of precipitation, settling thirty minutes, and sand filtration, at the rate of 50 gallons in six hours, or 2,000,000 gallons per acre daily, 80 per cent.

Fourth. Similarly the efficiency of precipitation and settling fifteen minutes was 80 per cent, while the addition of sand filtration at the rate of $4,000,000$ gallons per acre daily removed 86 per cent of the suspended matter.

Fifth. In another case the efficiency of precipitation and settling twelve hours was 92 per cent; of precipitation and settling eighteen hours, 86 per cent.

Sixth. The precipitation tank was run continuously, and two samples taken from the top showed 47 per cent, and fifteen minutes later 60 per cent, of the suspended matter removed. The gas bubbled up throughout the entire cross section of the precipitation tank. This constant ebullition prevented the suspended matter from settling as it should and as it would in a tank described later, in which the ebullition is confined to the delivery pipe, in which the flow is downward to the bottom of the precipitation tank.

Seventh. The waste and milk of lime were delivered at the bottom of the precipitation tank, where the gas was added, at the rate of 100 gallons in twelve hours. The effluent taken from the top was delivered into the bottom of a reservoir barrel. From the top of it ran two siphons--one to the coke and one to the sand filter-each discharging at the rate of 50 gallons per twenty-four hours, or 500,000 gallons

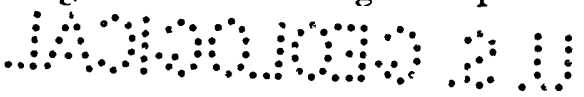


per acre daily. The precipitation removed 36 per cent of the suspended matter, and the coke filter removed 42 per cent of the remainder. At the same time the sand filter removed 66 per cent. The total efficiency with the sand filter was 79 per cent.

Eighth. The sludge drawn from the bottom of the precipitation barrel showed 9,88t parts per 100,000 of suspended matter, or 40 times that in the untreated waste.

\section{DISCUSSION OF TESTS.}

The above efficiencies are all figured on the basis of a single sample of untreated waste which contained 238.9 parts per 100,000 of suspended matter. To have taken a sample from each barrel would have increased the number of analyses by ten, and would not have effected the results materially. As it was, 21 analyses were made. Different barrels differ in the quantity of suspended matter, of total solids, and of calcium present. The quantity of lime was sometimes too great, and at other times the quantity of $\mathrm{CO}_{2}$ may not have been sufficient. These facts account for the discrepancies that arise. The average efficiency of precipitation in removing suspended matter from 10 cases was 63 per cent. The average efficiency of precipitation, settling for various periods, and sand filtration was over 85 per cent.

TABLE 5.--Analysis of sample of untreated waste from fourth barrel.

Suspended matter:

[In parts per 100,000.]

Organic residue 149.8

Inorganic residue 88.8

Total residue. 238.6

Total solids:

Organic residue 362.5

Inorganic residue. 181.0

Total residue 543.5

Calcium 160.6

Nitrates None.

Nitrites. None.

Chlorine 71.8

Ammonia, free .74

Ammonia, albuminoid .60

Reaction, alkaline.

Coloring, organic. 
TABLE 6.- Residue contained in suspended matter in samples 2 to 21.

\begin{tabular}{|c|c|c|c|}
\hline Sample. & $\begin{array}{l}\text { Total resi- } \\
\text { due. }\end{array}$ & $\begin{array}{l}\text { Organic } \\
\text { residue. }\end{array}$ & $\begin{array}{l}\text { Inorganic } \\
\text { residue. }\end{array}$ \\
\hline No. 2... & 125.8 & 57.2 & 68.5 \\
\hline No. $3 \ldots \ldots \ldots \ldots$ & 128.7 & 86.5 & 42.1 \\
\hline No. $4 \ldots$ & 23.5 & 16.0 & 7.4 \\
\hline No. $5 .$. & 17.7 & 11.0 & 6.7 \\
\hline No. $6 \ldots \ldots \ldots$ & 200.0 & 133.7 & 66.2 \\
\hline No. $7 \ldots \ldots \ldots$ & 215.0 & 160.3 & 54.6 \\
\hline No. $8 \ldots$ & 62.0 & 43.9 & 17.9 \\
\hline No. $9 \ldots$ & 24.0 & 14.0 & 9.5 \\
\hline No, $10 \ldots$. & 60.5 & 36.8 & 23.5 \\
\hline No. $11 \ldots . .$. & 48.0 & 29.3 & 18.6 \\
\hline No. 12. & 195.8 & 123.5 & 71.9 \\
\hline No. $13 .$. & 33.8 & 24.4 & 9.3 \\
\hline No. 14. & 152.0 & 105.3 & 45.6 \\
\hline No. $15 \ldots .$. & 88.8 & 61.0 & 27.6 \\
\hline No. $16 \ldots \ldots$. & 50.0 & 35.0 & 14.9 \\
\hline No. $17 \ldots \ldots$. & 126.5 & 75.3 & 51.1 \\
\hline No. $18 \ldots . . . . .$. & 89.5 . & 51.5 & 37.9 \\
\hline No. $19 \ldots \ldots$. & 19.0 & 12.5 & 6.4 \\
\hline No. $20 \ldots \ldots$ & 33.6 & 11.1 & 12.3 \\
\hline No. $21 \ldots \ldots \ldots$ & $9,884.0$ & $5,361.6$ & $4,501.5$ \\
\hline
\end{tabular}

Samples 2 and 4 were taken from the tops of the reservoir barrels. Samples 3 and 5 are of filtrates from the coke and sand filters, respectively, taken at the middle of each test. The barrel from which sample No. 2 was taken was run through the coke filter. The barrel from which sample No. 3 was taken was filtered through sand.

Reservoirs Nos. 1 and 2 were filled and permitted to settle one hour, after which samples Nos. 6 and 7 were taken from reservoirs 1 and 2, respectively. Reservoir No. 1 was then run through the coke filter and No. 2 through the sand filter at the rate of $1,000,000$ gallons per acre a day. Samples 8 and 9 are from the filtrates through the coke and sand, respectively.

Reservoir No. 1 was filled and allowed to settle thirty minutes. Sample No. 10 was then taken from the top. It was siphoned onto the sand filter at the rate of $2,000,000$ gallons every twenty-four hours. Sample 11 is from the filtrate.

Reservoir No. 2 was filled and allowed to settle fifteen minutes. Sample 12 was collected as the liquor was siphoned from the top of reservoir No. 2 onto the sand filter, through which it passed at the rate of 4,000,000 gallons per acre daily. Sample 13 is from the filtrate. 
The precipitation tank was run continuously, discharging into reservoir No. 1. From the top of the latter siphons led to the coke and sand filter. The rate of discharge from each was 50 gallons in twelve hours, or 1,000,000 gallons per acre daily. Sample 14 was taken from the top of the reservoir. Sample 15 was from the filtrate through the coke, and 16 from the filtrate through the sand.

Sample 17 was taken from the top of the precipitation tank during its operation, and sample 18 was collected fifteen minutes later.

Sample 19 was obtained from the top of the precipitation tank after it had settled for a period of twelve hours.

Sample 20 came from the top of the precipitation barrel after it had settled eighteen hours.

Sample 21 is of sludge drawn from the bottom of the precipitation tank.

The effect on solids in solution, especially on the calcium, was not so satisfactory, owing to the lack of sensitive apparatus by which to gauge the proper proportions of milk of lime. There was either an excess or a deficiency of lime, leaving an undesirable amount in the effluent. So long as the quantity of $\mathrm{CO}_{2}$ is sufficient to saturate the liquor no variation in it is needed, but for the most successful operation of the process the volume of lime should be automatically regulated by the rate of flow of waste.

MIXING APPARATUS.

English and American experience suggests that the waste, $\mathrm{CO}_{2}$, and milk of lime should be brought together during a downward flow, and that the precipitation should take place during a following slow, quiet, upward movement.

The milk of lime may be proportioned to the waste by a float in the chamber leading to the waste weir. This float would vary the length of a weir of constant head which feeds the milk of lime to the waste. The mixture should then travel down a central shaft through a nest of tubes perforated on the lower side, from which $\mathrm{CO}_{2}$ issues under about 2 feet of head. The treated waste now travels down the central shaft to the bottom of the tank, where the flow turns upward with a very low velocity. The less the upward velocity the greater the efficiency of precipitation. The effluent would be collected at the top in semicylindrical troughs.

In the tests above reported 50 gallons were run through a tank of 50 gallons capacity in one hour. The cross section of the barrel was 649 square inches, making an upward velocity of 0.005 of an inch per second. To treat $1,000,000$ gallons a day with the same upward relocity would require a tank of 83,300 gallons capacity, or 25 feet square and 15 feet deep. In the tests made the $\mathrm{CO}_{2}$ was distributed throughout the barrel, and the violent ebullition kept the precipitation from 
being satisfactory, unless 15 to 30 minutes be given or the effluent be run into settling reservoirs. By confining the ebullition to a central small cylinder, where the downward flow takes place, the efficiency of the precipitation would certainly be increased.

\section{PRODUCTION OF CARBON DIOXIDE.}

The most important problem in the application of this method of purifying strawboard waste is the production of the required amount of carbon dioxide in an economical and practical manner. Two methods of producing this may be considered.

First method.-Carbon dioxide may be produced by burning lime in closed kilns, such as are used in the manufacture of beet sugar. In the typical factory which we have assumed, using 50 tons of straw a day, nearly 10 tons of lime are needed in the process of manufacture, and an additional 10 tons are required for purifying the waste. A closed kiln of 20 tons daily capacity, with rock hoist and gas pump. would cost $\$ 10,000$. The operation would require 4,800 pounds of coke a day and the attendance of three men on each shift. Figuring interest, depreciation, lahor, and coke, the daily cost of $\mathrm{CO}_{2}$ produced would be $\$ 31.90$. Neither profit nor loss is figured on the lime. Finally, the quantity of $\mathrm{CO}_{2}$ would be only about 25 per cent of that required. To produce 80 tons of lime a day would necessitate a correspondingly great outlay and the production of 60 tons of lime for which a market must be found. Manifestly the method does not recommend itself, especially in comparison with the following one.

Second method.-At the plant which has been cited, where 50 tons of straw are used each day, about 80 tons of Brazil (Ind.) bituminous coal are burned every twenty-four hours. This coal contains about 70 per cent carbon. Consequently, 70 per cent of 80 tons, equaling 56 tons, or 112,000 pounds, of carbon are consumed each day. About 12 pounds of air per pound of carbon are necessary for combustion. In the average hand-fired furnace an excess of 50 per cent of air is supplied, making 18 pounds of air per pound of carbon. In the above case there would be 18 times 112,000 , or $2,016,000$, pounds of air needed. A series of 16 tests reported shows that the per cent of $\mathrm{CO}_{2}$ in the chimney gases ranges from 8 to 19 per cent. Assuming 10 per cent as a conservative amount, there would be 10 per cent of $2,016,000$, or 201,600 , pounds of $\mathrm{CO}_{2}$ available every twenty-four hours from the flue gases. The maximum amount of carbon dioxide needed in the precipitation is twice 19,800 , which equals 39,600 pounds. Only 20 per cent of the chimney gases would be needed in the process of purification. Gas pumps capable of delivering 250,000 cubic feet per twenty-four hours, under the pressure of 2 feet of water, would be required. 
The cost for gas pump and installation would be $\$ 2,500$, with no additional attendance above the usual engine-room staff. Figuring cost on the same basis as before, it would amount to $\$ 1.35$ per diem, as compared with $\$ 31.90$ in the previous case, a saving of $\$ 30.65$ a day. The actual cost of producing the necessary lime and $\mathrm{CO}_{2}$ would be the cost of 10 tons of lime at $\$ 5$ per ton, or $\$ 50$, plus $\$ 1.35$ for pumping, making a total of $\$ 51.35$ daily.

The cost of installing a precipitating tank and mixing apparatus is so dependent on local conditions that no figures can be given unless the conditions be known. In almost all cases the design could be adapted to the topography, so that it would be unnecessary to pump either the waste, the effluent, or the sludge.

While it is believed that under average conditions filters are not needed, if a higher degree of purification is required at times of very low stream flow than the normal operation of the precipitation tank provides, gravity filters could be employed. Under some conditions a second settling tank, or two precipitation tanks with a reduced rate of flow, might be the more economical. To operate a filter requires an available head of about 3 feet from the surface of the tank. To operate two tanks either in series or in parallel requires practically no additional head.

\section{TREATMENT OF SLUDGE.}

Would it pay to treat the sludge in order to recover the lime? Take, for example, the 50 -ton mill which wastes 19,800 pounds of lime daily. Assuming an efficiency of 75 per cent in the purification by precipitation alone, there would be present in the sludge 75 per cent of twice 19,800 , or 29,700 , pounds of lime. Only about 85 per cent of this is recoverable, i. e., 26,700 pounds.

No more economical method of drying the sludge is known than that employed in the manufacture of strawboard itself. Hence the cost may be considered the same. An official of a strawboard company states that the hot rolls receive the pulp from the wet end, press it while it is about 66 per cent water, and deliver it with about 10 per cent of moisture remaining. The cost of removing this 56 per cent of water present is the principal item in the expense of drying. The company estimates that it requires 11 horsepower for twenty-four hours, or 264 horsepower hours, to dry 1 ton of board. If we take 30 pounds of steam as equivalent to 1 horsepower hour, then $11 \times 24 \times 30$, or $\tau, 960$, pounds of steam are required per ton of product. If 7 pounds of steam be generated per pound of coal burned, 1,274 pounds of coal are consumed, which, at $\$ 3$ per ton, makes the cost $\$ 1.91$ per ton of product. One-half the cake is straw and one-half carbonate of lime, hence the cost per ton of lime present is $\$ 3.82$. 
After the sludge is dried to the consistency of strawboard it would still contain 10 per cent of moisture. To remove the remaining moisture and make the lime available as an oxide the cake must be burned in a limekiln fired with coke, in order that the calcium carbonate shall be reduced to the oxide, thus completing the cycle through which the lime has passed. The cost would be greater than that of burning limestone, because of the greater moisture present. In addition there would be a considerable quantity of the silica present in the ash of the straw. The ash is about 5 per cent of the weight of the original straw, and of this 73 per cent, according to Remsen, will be silica. The major part of the ash would be accumulated waste material unseparated from the lime. It would evidently cost more to recover the lime in the sludge than it is worth.

The particles of straw are so fine that they will not work up into even a second-grade board. In fact, no use for this material has been discovered, hence its waste. The process of manufacture is so very wasteful, then, partly because present methods can not make this finer portion into salable stock.

The question of making a separate product from the sludge was raised. This material contains lime and silica principally. Would it make boards similar to asbestos boards to serve as nonconductors to heat? Whether or not the material, pressed and bonded by cloth, would make a nonconducting article like felt has not been carefully considered.

English patent No. 16966, issued August 6, 1898, covers a process of fireproofing wood or straw by treatment with carbonate of potash, boric acid, sulphate of magnesia, and sulphate of ammonia (see Jour. Soc. Chem. Ind., August 31, 1899, p. 763). The method would not be commercially applicable in this case in view of the ruling prices of felt and asbestos. At present it seems that the only rational way to dispose of the sludge is to run it out on the ground.

\section{CONCLUSIONS.}

1. Strawboard waste is an extremely stable substance which does not degenerate when kept in clean containers, but when mixed with other substances of a putrescible nature, such as sewage and otber organic matter in streams, it becomes very foul and objectionable.

2. Simple sedimentation is not effective in the purification of strawboard waste.

3. Chemical precipitation appears to be satisfactory from every standpoint except that of cost, which makes it commercially impracticable.

4. Filtration without previous sedimentation is impracticable, but combined with sedimentation is an aid to the process. 
5 . The sulphates of iron and alumina are the most effective chemical precipitants for the purification of strawboard waste, but so large are the amounts which it is necessary to use that the cost is prohibitive.

6. Lime is of no value as a precipitant.

7. Carbon dioxide has no effect upon the suspended matter in strawboard waste.

8. The combination of carbon dioxide and milk of lime is effective when properly applied, and the process can be economically maintained if conditions are favorable. 'The results of experiments indicate that 75 per cent of the suspended material can be removed by precipitation with carbon dioxide and milk of lime at high speed of treatment. Higher efficiencies an be obtained at lower speed and by the combination of sand filtration. It is believed, however, that the latter would be necessary only in extreme cases.

\section{SUPPLEMENTARY NOTE.}

The objection raised hy the officials of the United Box Board and Paper Company to the purification process described in the preceding pages is based upon its cost. It is maintained that the different kinds of box board now upon the market are so evenly balanced in cost of production and competitive selling price that the additional expense incurred in manufacture, which would result from the adoption of this process, would drive strawboard from the market. Nevertheless, it is hoped that the experiments here recorded may stimulate interest in the question considered and aid in directing research that will lead to a satisfactory solution of the problem. 


\title{
DISPOSAL OF OIL-WELL WASTES AT MARION, IND.
}

\author{
By Isaiah Bowman.
}

\section{INTRODUCTION.}

Since 1886, a date which marks the beginning of the oil and gas industry in eastern Indiana, there has been more or less speculation concerning the pollution of wells and streams in the oil fields in so far as such pollution impairs the purity of drinking water or damages water for domestic and industrial uses. Within the last few years the matter has assumed a more serious aspect. Considerable litigation has resulted from attempts to collect compensation for damages to surface wells by this form of contamination.

In the following pages the manner in which such pollution occurs is shown, and a remedy is suggested for the conditions. The data presented relate to the city of Marion, this city having been chosen as the place of inquiry because it is situated in the center of the oil fields of eastern Indiana and because many cases of well and stream pollution are known to exist there.

Acknowledgments are due to Mr. E. Hulley, superintendent of the Marion waterworks, and Messrs. John E. Weigel and W. L. Benson, well drillers, for assistance rendered by them in preparing this paper.

\section{TOPOGRAPHY AND DRAINAGE OF THE REGION.}

The city of Marion is located on Mississinewa River. This stream is tributary to the Wabash and has a length of about 100 miles. The general course of the stream is northwestward, and the channel lies just outside the Mississinewa moraine. Above Marion the river swings against the moraine, cutting steep bluffs into the clay; but near the Arcona bridge, between Eighteenth and Nineteenth streets, it cuts into a gravel terrace formed outside the moraine by the stream when it was overloaded by material derived from the ice which then rested against the moraine. Just opposite Marion-onthe-River, and again near the Washington Street Bridge, the Mississinewa flows over rock. This greatly impedes the dissection of the till plain and terraces in which the river valley has elsewhere been 
incised. The difference in the character of the material that the river must remove has resulted in alternate straight and meandering stretches. Each outcrop of rock in the channel is generally indicated by a marked sinuosity of the stream above it.

Back of the river bluffs, which have an average height of about 50 feet, the surface of the country to the southwest is extremely level, and drainage, especially on the flat and wide divides, is sluggish and ineffective. Northeast of the river the Mississinewa moraine gives some relief to the surface, although that part of the moraine near Marion has an average height of not more than 20 or 30 feet.

The valley bottom varies greatly in width. In places it is but little wider than the river, while in the vicinity of the pumping station it is from a half mile to a mile wide. The business part of the city and its more thickly settled portions lie on an old flood plain of the Mississinewa. The oil wells are scattered over the whole region, alike in valley bottom and in the country back of the river bluffs. Occasionally, where the bluffs have a gentle descent, oil wells may be found on them, as well as on the lower surfaces nearer the river, positions which have the advantage of rapid drainage, while the others have the association of stagnant pools of waste oil.

\section{GEOLOGIC FEATURES.}

\section{PLEISTOCENE IDEPOSITS.}

At the place where Sixth street ascends the river bluffs in the western part of the city there is a typical 30-foot section of the till plain. Beneath a covering of till about 10 feet thick is a layer of gravel, which in turn overlies a layer of iron-stained bowlders several feet thick. Below this is a promiscuous deposit of clay and gravel, underlain by cross-bedded and fine-textured sand.

The upper covering of till is persistent throughout this region, varying in thickness from several inches to 15 feet. It is, of course, absent in the valleys where the river has undercut it. Where it is thin it is very porous, because of oxidation and the action of vegetation, so that it offers no obstruction to the free passage of percolating water. Along the present stream channel and over the older flood plain that lies between the bluffs are scattered bowlders which the river has been able to undermine and dislodge from the bowlder bed previously mentioned, but which it is not able to carry downstream. In places the till is so free from pebbles that it is used in the manufacture of brick.

A number of well sections are given herewith, since they represent the character of the glacial deposits, an understanding of which is essential to an appreciation of the conditions of water contamination. The best well section procured in the vicinity of Marion was that 
obtained at the pumping station of the city waterworks. At the request of the writer samples of the borings were saved by Mr. E. Hulley, superintendent of the waterworks. The well was drilled in Octoher, 1903. In studying the section it must be remembered that the pumping station is in the ralley of the Mississinewa and that the bluff section given above must be added to the well section in order to get a fair notion of the character of the deposits from the surface of the till plain to the rock.

The samples were examined both microscopically and macroscopically. A description of them follows:

Section of well at city wateruork, Marim, Ind.

1. Fine sand and black loam (a peaty deposit in a part of the river channel now abandoned )

2. Very fine, yellow, sharp, ferruginous sand

3. Coarse gray sand, the grains being rounderl through water

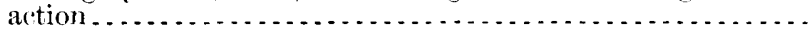

4. Fine gravel, made up mostly of erratic material and quartz sand.

5. Pale reddish-brown clay with many stones and considerable gravel, also some iron concretions. The stones and pebbles were of chert, limestone, trap, shale, and quartzite. (Limestone, shale, and chert pebbles seem to have been derived from the underlying rock) .

6. Gray clay, very plastic when wet and containing no pebbles. This clay is remarkably pure and is distinct from the clay bed above it in containing no pebbles whatever in its middle portion, though it merges gradually into the pebbly clay above.

7. Limestone (Niagara). The limestone is water bearing from the top to the last depth given and presumably beyond, but the best supply comes from a subporous and greatly fissured

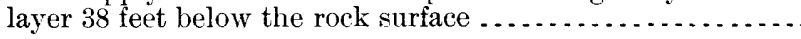

This is a flowing well, the water rising (when the well is piped up) to a height of 18 feet above the surface.

The following boring records were kindly furnished by Mr. John E. Weigel, of Marion, Ind. They show the character and depth of the material overlying the rock at the various places indicated by the corresponding numbers on the accompanying map (fig. 4).

Material overlying rock at certain localities indicated by numbers on fig. 4.

1. Sand and gravel

Feet.

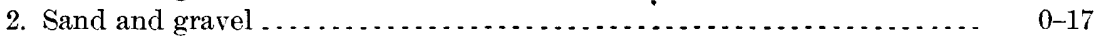

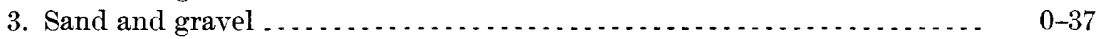

"Blue" clay ............................................ 37-45

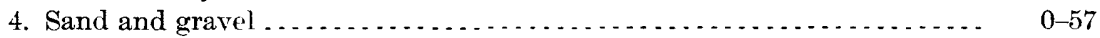

"Blue" clay .......................................... $57-65$ 
5. Gravel

Mixture of gravel, sand, and clay.

6. Gravel and sand ....................................... $0-50$

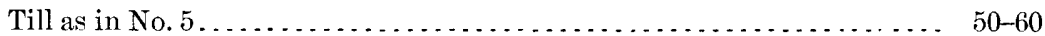

7. Rock in river bottom .................................. 0

8. Till, sand, and gravel . . . . . . . . . . . . . . . . . . . . . . . . . . 0 .

9. Sand and gravel ........................................... $0-32$

10. Sand and gravel ........................................... $0-60$

11. Gravel... . . . . . . . . . . . . . . . . . . . . . . . . . . . . . . ${ }^{0} 0-40$

Till................................................. 40-100

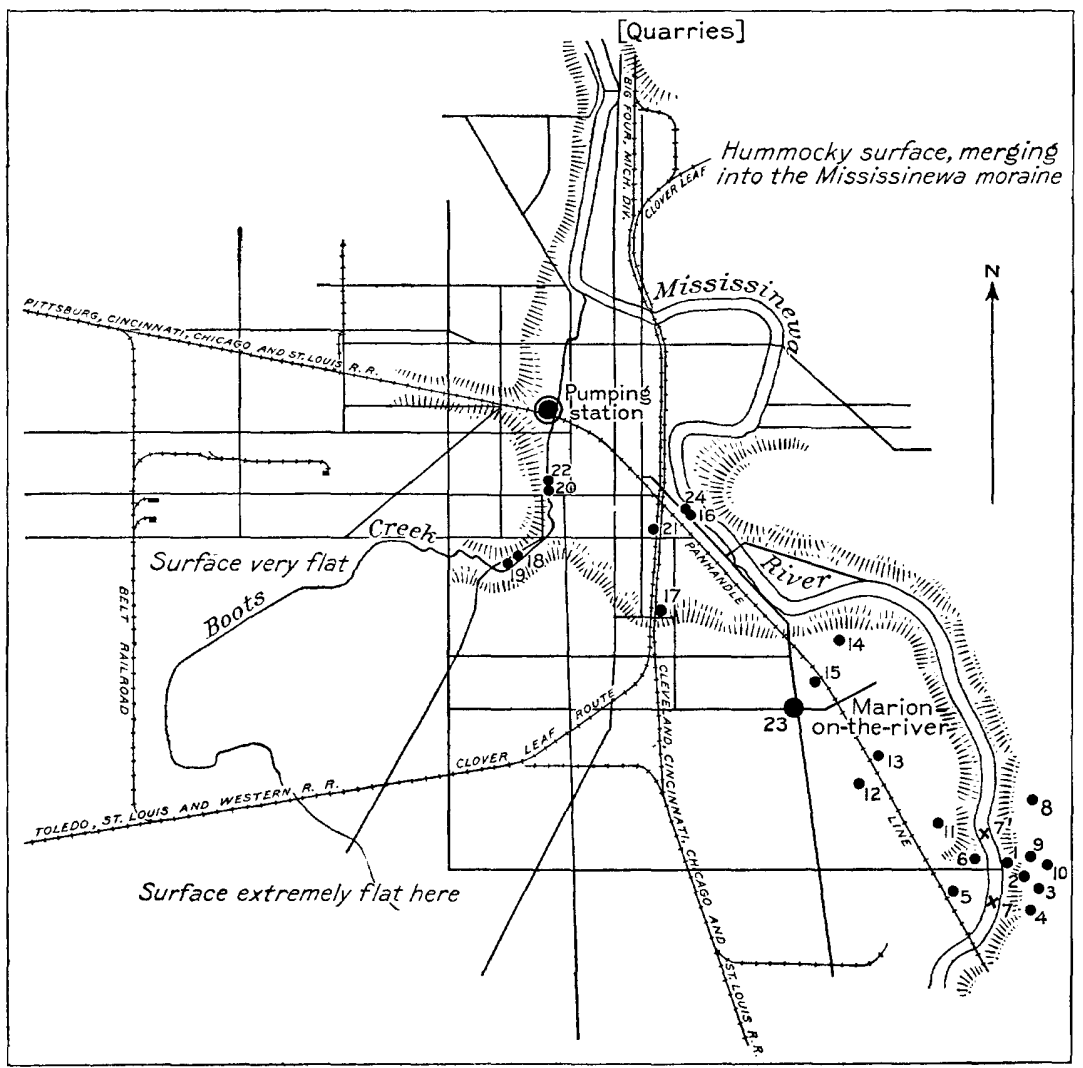

FIG. 4.-Map of Marion, Ind.

12. Till, sand, and gravel . . . . . . . . . . . . . . . . . . . . . . . . . . 0.200

13. Till, sand, and gravel ................................. 0 .200

14. Gravel................................................ $0-50$

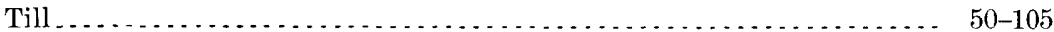

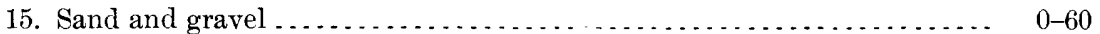

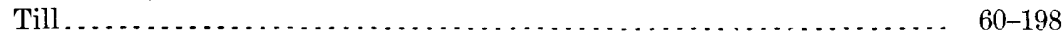

16. Quicksand . . . . . . . . . . . . . . . . . . . . . . . . . .

Till (mostly gravel and some brown clay) . . . . . . . . . . . . . . . . . $55-200$

17. Gravel, bearing salt water . . . . . . . . . . . . . . . . . . . . . . . . . . . . $0-40$

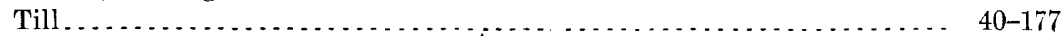

18 and 19. (The samples previously referred to are from these two wells.) 
20. Sand and gravel $\ldots$

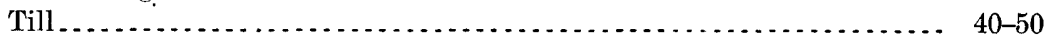

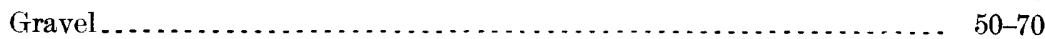

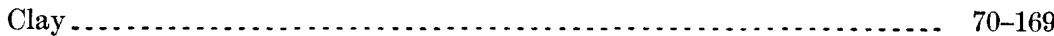

(This well was drilled 118 feet into limestone, making a total depth of 287 feet, but no water was encountered, and the well was abandoned.)

21. Sand and gravel .......................................... $0-60$

Till.......................................................... 60-117

Gravel.... . . . . . . . . . . . .

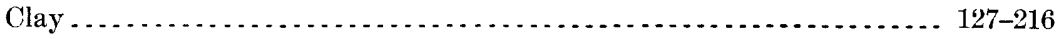

While the last clay bed is extensive, it by no means covers the entire surface of the rock, for well sections frequently show glacial gravel and till all the way to rock. No bowlders are known to occur in it, and the deposit may be nonglacial. Gravel is said to underlie it in places, but none of the gravel was obtainable, and its nature is therefore uncertain.

In the foregoing records no distinction was made between this clay bed and the pronouncedly glacial material overlying it, although an examination of the samples showed that such a distinction exists.

The well sections show that there is an extensive area of rock surface not covered with clay, the entire section yielding only sand and gravel. It also appears that the upper layers of clay, or more properly, of till, and the layers of gravel are in many places differentiated, while in others there is a more or less intimate mixture of these two materials. Such a mixture must not be regarded as impervious to water. There is undoubtedly a more or less free circulation of subsurface water throughout this entire mass of glacial material. This conclusion is warranted not only by a determination of the frequent high porosity of the till and its consequent permeability to water, but also by underground observations on percolating water. In assisting Mr. A. (. Veatch, of this Survey, in work done on Long Island, New York, during the summer of 1903, the writer had occasion, through the kindness of Mr. J. C. Meem, consulting engineer for the Borough Construction Company, to examine a sewer tunnel in course of construction between Sixty-fifth street and Fort Hamilton avenue, South Brooklyn. Different working faces were closely examined, and it was found that even in those places where the till was most clayey in composition the water at a depth of 90 feet from the surface had occupied the pores of the till in such manner and to such a degree that constant pumping was necessary to keep this part of the tunnel dry enough to permit work. The sand and gravel distributed through the till was sufficiently abundant to allow a constant flow of underground water. This fact must be regarded as important, inasmuch as a number of apparently anomalous cases of contamination no doubt depend for their explanation upon this quality of the till. 
HARD ROCK FORNATIONS.

The hard rock formations with which this report is concerned are the Niagara limestone, the shales and limestones formerly known as the Hudson River limiestone and Utica shale, and the upper Trenton limestone.

NIAGARA LIMESTONE.

Into the Niagara limestone pre-Glacial streams cut valleys several hundred feet deep. This depth was so great that the ice sheet was just able to cover the valleys and divides evenly with drift, and so enable the post-Glacial streams to take an initial course independent of the old rock valleys. The depths to rock at rarious places in Marion and in the region east of that city indicate that the pre-Glacial drainage was along a northeast-southwest line, almost at right angles to the general direction of the course now taken by the Mississinewa. In some of the deeper parts of this old valley the limestone has been completely eroded and the shale beneath uncovered, while over a considerable area near the bottom of the valley the limestone is but a few feet thick. Toward the divides it becomes thicker, reaching a maximum thickness of about 350 feet at the quarries indicated on the map.

The upper layers of limestone are weathered to a depth of 6 or 8 feet, the result being the formation of a dirty yellow and partially oxidized clay. In most places this clay is porous, usually covering the rock to an insignificant depth. Most of this clay was removed during the advance of the ice. It occurs at the present time only in patches, which furnish all the evidence that is available concerning pre-Glacial conditions.

The limestone lies in nearly horizontal layers. It is extensively firsured, the breaks being more numerous near the top of the section, presumably from pre-Glacial weathering, the weight of the once overlying ice, and the extremes of temperature to which the rock was subjected and the water which it contained. This condition of the limestone permits surface water to have easy access to the rock for some depth, and rock wells and springs (the latter where the rock outcrops in a favorable way) are therefore to be expected. Such springs exist in all the quarries, and the chief source of the city water supply is from wells drilled into the upper limestone rock.

It is maintained by the writer that the water occurring in the upper limestone rock is not derived from some far distant source and transmitted through possible porous layer's of limestone, but is essentially of local derivation and is supplied from rainfall percolating through the glacial deposits above. This conclusion is supported by the following considerations:

1. Water must enter the limestone where it is not covered with clay. 
2. Once in rock which is fissured and to a slight extent porous, the water must ultimately ocempy even those parts of the rock that are corered with clay.

3. The greatest supply of water is found near the top, where the limestone is most highly fissured and where, therefore, the transmission of pressure is most quickly accomplished.

4. 'The deep valleying which the limestone has suffered and the consequent relation of the superimposed clay beds to the shale and the eroded edges of the limestone prevent the wide distribution of pereolating water through possible porous limestone layers.

5. The rock is unevenly tissured. If there is any connection between the fissured condition and the supply from above, we should expect the greatest supply where the rock is most highly fissured; also a considerable disparity in the depths of wells, even though such wells are within short distances of one another. Many examples of the latter condition are found among rock wells.

6. 'The rock being unevenly fissured and of different degrees of porosity, a combination of unfavorable conditions may result and no water may be procurable from the rock in some places. Such conditions have been known to occur, although the number of cases is rare. One of the most notable occurred in November, 1903, when a boring was made for water by the city waterworks company. On the map the well is indicated by the number 2:. The following material was encountered:

Sestion of dry boring at Marion, Ind.

(1) Sand and gravel.

(2) Mixed gravel and clay .................................. $50-169$

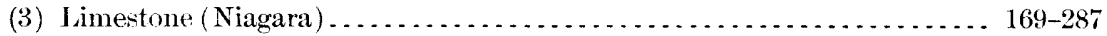

Note.-No water was obtained and the hol was abandoned.

7. So far as the writer has been able to determine, there are no successful wells in the limestone at any depth where the limestone comes very near to the surface, while in the valleys the wells in the rock are scarcely ever unsuccessful and they nearly always flow.

HUDSON RIVER LIMESTONE AND CTICA SHALE.

This group occurs about 365 feet below the surface and is about 560 feet thick, the Trenton limestone beginning at about 925 feet. The shales are somewhat calcareous, and near the top and bottom of the series there are frequent intercalations of bluish thin-bedded limestones. The formation is not water bearing except near the bottom, where water, saline in quality, sometimes occurs.

TRENTON LIMESTONE.

This limestone is dull gray in color, except where it is most calcitic, and there it is nearly white. Oil occurs near the top of the forma- 
tion, where the rock is extremely porous. Beneath the oil is salt water, which is pumped out with the crude oil in large quantities. If pumping is continued irregularly the oil well may he permanently injured hy the inflow of salt water. In the earlier days of oil wells the driller frequently driiled to too great a depth and the inflow of brine was so strong that the well became useless. In order to form a reservoir for the collection of oil the limestone must be entered some distance, and the most successful wells are those which are drilled deep enough to allow a large amount of oil to collect and still be some distance above the upper level of the brine. The oil wells are usually about 1,050 feet deep, the oil rising to within 600 or 700 feet of the surface.

\section{SOURCES OF CONTAMINATION.}

Scarcely a week passes but the boring of an oil well near Marion is completed and the well is "shot" with nitroglycerine. The shooting, no doubt, breaks up the porous Trenton limestone and forms fissures and small caverns, which act as reservoirs into which the oil will flow if this substance occupies the pores of the rock at that place. The surface effect of the shooting is the riolent ejection of salt water and oil, often to the estimated amount of thousands of gallons. The oil and salt water sink into the soil, where it is sufficiently porous, and finally reach the surface zone of underground flow, where they partake of the general movement of the water toward the main line of underground drainage.

Wells reaching this saturated zone and lying between the oil well and this line of drainage, or thalweg, become polluted. This takes place eren though the amount of oil contributed during a week or a month should be small; for the oil, being lighter than the water and having greater riscosity, is subject to less favorable conditions of lateral flow, and the ratio of the amount of it in the well to the height of the vertical water column of which it forms a part tends to be greater than the ratio expressing a normal condition elsewhere in the saturated zone.

By a similar process of reasoning we are led to believe that the hrine, but not the oil, should pollute wells which derive water from deeper zones of flow or from the bottom of the surface zone. This will be true especially where depressions occur in the clay of the drift, or along the main line of underground drainage. This conClusion seems to be supported, in part at least, by the records given elsewhere in this paper, its final justification depending on its accordance with a larger amount of data. The slope of the ground being usually indicative of the direction of flow of underground water, an examination of the surface slopes with reference to a near-hy water well should indicate whether or not pollution may arise in a given locality through the circumstances attending the sinking and working 
of an oil well. In sinking water wells, depressions in the drift should he avoided, as well as the deeper parts of the valley. As will appear more clearly later in this discussion, howerer, the burden of responsibility for contamination rests not on the owners of water wells but on the owners of oil wells, for the latter are usually in the field later than the former and locate their wells often with no regard to the rights of others and in contempt of well-established theories of contamination.

If the contamination of wells were due alone to the oil and salt water which is thrown out at the shooting of a well the number of cases of pollution might be much smaller than it is now, for a great deal of the liquid thrown out runs off quickly into the creeks, and only a part of it, except where the surface is level or the ground porous, sinks into the soil. There is another and more prolific source of contamination. The brine and oil pumped from an oil well are delivered to a tank having a capacity of 100 barrels or more. Near the bottom of the tank a pipe leads up at an angle with the side, and it is through this pipe that the salt water is allowed to escape. (See Pl. IV.) A little below the level of the top of the liquid in the tank another pipe leads off. It is through this one that the oil is conducted. The adjustment of these two pipes is made with reference to the capacity of the well, so that but little waste of oil occur's from this source. Some, however, does find its way out of the pipe intended to convey only salt water, and this oil, together with that which is derived from various leaks in the tank and from pumping, result in a constant flow of brine and oil from the well and tank. In many cases the owners of these wells pay no attention to the disposition of this refuse, but allow it to lie in pools or to run slowly over the adjoining fields. Some of it finds its way into the creeks and so into the river, while still another part sinks slowly into the ground. In some cases the attention of owners has been called to the danger of pollution, but only a few of them take the precaution to construct a ditch from the well to the nearest ravine or creek.

It is instructive in this connection to note the manner in which pipes are inserted into the bore holes in rock and the danger of pollution resulting from this method. An 8 -inch pipe, called a drivepipe, is driven down through the various materials above the rock as rapidly as the material at the bottom of the pipe can he removed by means of a sand bucket, and is then forced into the upper limestone to a distance of from 5 to 15 feet. With the largest drill that will work in the casing the hole is continued down through the upper limestone as far as the shale overlying the Trenton limestone. Here the size of the bit is reduced, and, after the hole is drilled some distance into the shale, the hole is cased with a $5 \frac{5}{8}$-inch pipe. The shale itself contains no water, except very small amounts near its hase, but the limestone overlying 


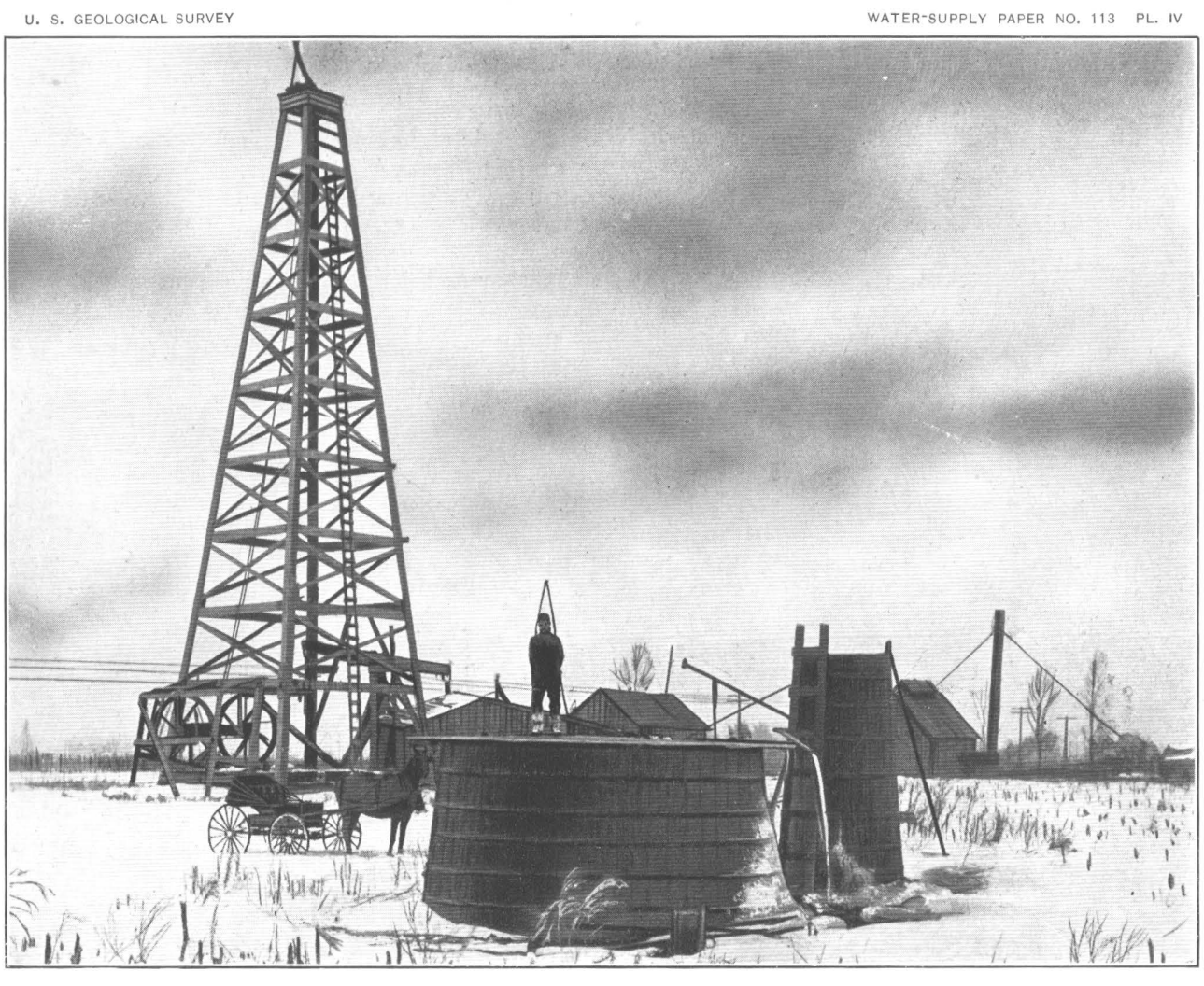

RECEIVING TANK WITH DISCHARGE PIPES 
it is saturated. It is the effort of the driller to so tightly fit the casing into the shale that no water from the overlying limestone can follow down the pipe to its open lower end. Such a passage along the pipe would either allow the oil to escape upward, or the surficial waters, with sand, clay, etc., to pass downward into the oil, according to the direction of circulation.

The space between the casing and the sides of the hole in the limestone permits such oil and brine as have passed downward through the soil to have easy access to the waters in the limestone. This takes place oftenest where the limestone is near the surface and where the material above it consists wholly of sand and gravel. The water in this loose material will tend to move nearly vertically downward, but contamination will occur with almost equal certainty where the direction of movement has a strong horizontal component, the wolls being so numerous and crowded that the refuse from one readily contaminates the water in the rock adjacent to others. In the vicinity of the Thirty eighth Street Bridge the water table stands from 30 to 35 feet below the surface, showing that the movement of whatever additions it may be receiving by downward percolation from the surface must be nearly vertical, as evidences of lateral movement, as expressed by any rise of the water table, are absent. The water level in the rock at this and similar places seems to supply additional proof of the local sources of the water. The flowing wells in the valley are at least 50 or 60 feet lower than those about 'Thirty-eighth Street Bridge, and the height to which the water will rise in the strongest of the flowing wells seems to be always somewhat less than the height of the water level in adjacent areas. Precise levels run to the various wells would furnish data of great value in settling questionable points of this nature.

Where artesian effect is pronounced pollution from the source under consideration may not be accomplished as readily, though it seems that in time the inflow of salt water near the head would contaminate most of the water in the rock. 'The likelihood of such an occurrence is being strengthened continually because of the constantly increasing number of oil wells. The water from many rock wells shows at the present time an extremely high percentage of chlorine, and it is quite possible that it is now derived from that source, though, because of the relatively small amount delivered, diffusion does not allow the result to be so noticeable as it may in time become when the supply is increased.

It has been shown before that a differentiation of the refuse from an oil well may be expected to take place, the oil remaining undiffused and comparatively near the surface, while the salt water sinks down until diffusion destroys the disparity existing between the specific gravities of the brine and the water derived from rainfall. There is, therefore, more danger arising from the complete contamination of 
wells near the surface by means of oil than in the case of deeper wells from brine. This is true especially where the water table is lowered through excessive pumping. Any oil near the surface will be induced to assume lower and lower levels until, as pumping increases, it is drawn into the pipe. The example of this occurrence quoted below is all the more interesting when it is known that the above deduction was reached before examples of this sort of thing were known.

"On December 1," writes Mr. Hulley, "the water wells [ 24 on the map] of the Indiana Brewing Association, at Marion, began pumping oil. They are 160 feet deep and in gravel. They are flowing wells, but the flow not being sufficient, pumping by means of air lift is resorted to. When the amount of oil in the water becomes too great the pumps are stopped, and after standing for some time, so that the wells begin to flow, oil ceases to occur in the water. When pumping is resumed no oil is noticeable until the water level is lowered considerably through pumping." Mr. Hulley says further that the oil is without odor, showing that it has been purified by passing through sand and gravel and that it has evidently gotten into the ground from some distant source, as there are no oil wells near by.

There are thus seen to be two chief sources of danger of contamination. Oil and brine may escape between the casing and the shale and, rising to the porous or fissured layers of limestone, may contaminate the water therein, or they may sink down through the soil from stagnant pools of refuse at the surface. The danger arising from the former source seems to be very small, for, considering the height to which the oil will naturally rise and the fact that the oil wells are frequently not pumped for a day or two, the return of the oil from the outside of the casing into the well would be accompanied by an inflow of sand which would he destructive to the well. This is probably but seldom the case. Where wells have been sand choked it has not as yet been definitely proved whether the source of the sand was from above or below, the difficulty being that in both cases it would be derived from limestone. Until this danger has been proved to be actual no regulation by law will or should be attempted.

Regarding the latter source of danger, from water seeping through the soil from above, there is pretty conclusive proof. Moreover, the evil effects of the condition are so widespread and the remedy is so simple that the disposition of oil refuse should be made a subject of legislative enactment. In the country districts there is little need for vigilance beyond securing the quick removal of oil refuse to the nearest stream by means of ditches and the intelligent selection, with reference to the probable movement of the underground water, of sites for oil wells. It is in the thickly settled parts of the State, in villages and cities where water wells are more numerous, and where they can not always be properly located, that the need for a remedy is most 
urgent. The oil wells are, as a rule, yielding a lavish return to their owners, and there is no reason why these owners should not be compelled within proper limits to join in the construction of sewers which will convey oil refuse to the river.

The streams in this region are all more or less polluted, the water having an exceedingly unpleasant odor and a yellowish-white color. This is the color of the brine as it is pumped from the wells and is due to the presence of sulphur. From time to time public interest is aroused by the unsightly condition of the streams and there is much discussion in regard to the disposition of the water. In Marion the discussion centers about Boots Creek, for it is this creek which runs through the city and is thought to endanger health. At the present time there is under consideration the building of an aqueduct for the transportation of this water to the Mississinewa.

Regarding the healthfulness of these streams, it is noteworthy that before the beginning of the oil and gas industry they were so sluggish that in the dry season, when they were a mere succession of pools, the stagnant condition of the water, aided by the addition of sewage and foul vegetable matter, resulted frequently in typhoid fever, while at the present time, owing to the steady contributions from oil and gas wolls, there is active circulation of water throughout the entire year.

Dr. W. A. Fankboner, of Marion, has this to say about the condition of Boots Creek: "Its condition now is more healthful than before oil refuse was turned into it. To be sure, to some people the odor is unpleasant, hut the stream is not overgrown with weeds and covered with slime, as it formerly was at certain times of the year; and the oil has made it unpleasant as a breeding place for mosquitoes." He also says that there is no ground for the charge that more cases of typhoid fever have occurred along this creek than along other creeks but slightly polluted.

The consideration of all the foregoing possibilities, together with the fact that the city of Marion depends for its water supply upon rock wells (the surface wells not supplying an adequate amount), makes the danger seem very grave.

There are at least 75 oil wells in a few square miles of territory near Thirty-eighth street Bridge, where clay does not overlie the rock. The amount of oil refuse that finds its way into the limestone is enormous, $200 \mathrm{or} 300$ surface and rock wells ir this area, according to Mr. Weigel, suffering contamination, and unless this refuse is drained off into the river and not allowed to sink into the soil the gravest fears may be entertained for the continued purity of the city of Marion's water supply. A number of these wells were visited and the water examined. Among them were those belonging to Doctor Snodgrass and Messrs. Vansky and Keene. The location of these three wells is indicated on the map by the number 23 (p. 39). In other 
places, where clay overlies the rock to some thickness, the present danger may not be so great, although ultimately, because of the nature of the source from which all the water in the upper limestone is derived, the water will become contaminated even at these places.

With reference to this point, it has too long been the custom to make light of a situation that in a year or so may become very grave. Deeper sources of good water are unknown in this part of the State. The shale beneath the Niagara limestone yields practically no water, the little it does yield being saline, while still deeper is the Trenton limestone, full of oil and brine. Neither can the water from the streams be utilized, the constant inflow of brine and oil from adjacent oil wells rendering this plan impossible. Here practically the single source of the water supply of 27,000 people is threatened, and yet no adequate interest is aroused and no means are taken to prevent the danger.

The plea has been made that it is a necessary evil. The recent epidemic of typhoid fever at Butler, Pa., was due to just as "necessary" an evil, but that outhreak not only made the so-called necessity appear diminutive but made the neglect of such conditions seem criminal. It is not inferred that the same disease will follow the contamination of water through oil and brine, but it is inferred and emphasized that the disconfort and expense attending such contamination and the consequent lack of pure water may result in evils quite as great.

It is not sufficient to begin a study of remedies after mischief has been done. If even the probability of pollution of city water is proved, prompt means should be taken to prevent such pollution. 


\section{SUPPLEMENTARY NOTE.}

\section{By Marshall Ora Leighton.}

To carry oil-well wastes as directly as possible into running streams of water in accordance with the plan recommended in the preceding pages for the relief of ground-water supplies from pollution by oil and brine involves the direct pollution of the streams to an extent even greater than they are now contaminated in the oil fields. The question immediately presented is whether it is better from an economic standpoint to preserve local ground waters at the expense of surface waters which in flowing downstream affect wide areas, or to conserve the interests of many riparian owners below and, so far as may be possible, to retain these wastes in the immediate localities from which they are derived. It may be argued that any locality in which oil wells are developed has, by reason of that development, such extraordinary ecomonic advantages that it may well afford to suffer for any incidental loss which may arise from waste oil and brine. And is not the pecuniary advantage which follows the discovery of oil entirely compensatory for the loss of water resources? On the other hand, if the polluting matter is turned into the streams it destroys the value of water to lower riparian owners, who at common law have a right to that water in its purest natural state. The result of such procedure would be to relieve the fortunate oil region from an unfavorable feature which it is amply able to bear-in other words, to enable it further to enrich itself at the expense of districts that are unaided by the presence of oil deposits. Yet with reference to the other side of the question, it may be said that if all possible precautions were taken to hold oil and brine waters within the oil regions there would still be a pollution of rivers nearly if not quite as complete as would arise from carrying out the plan suggested by Mr. Bowman. There is no doubt that where oil deposits are developed stream pollution is inevitable. The rain which falls upon the earth will carry with it oil and brine which it encounters on the earth's surface. In addition to this, the percolating water will reach the lowest level, and whether this water be rain or oil and brine the streams will still be polluted. 
On the other hand, the people living in the oil regions must have sweet water for domestic purposes. This is a necessity which transcends all other economic demands. As shown in Mr. Bowman's discussion, the rivers in the Marion region are already unavailable as sources of pure water supply. and the only supply remaining is ground water. Therefore, as we can not save the stream and can save the ground water, there appears to be no question concerning the wisdom of accomplishing the latter end. Stream pollution in this case, as in certain others, is a part of the price paid for the accumulation of natural wealth. It can be considered an inevitable loss with equanimity, as it is only a temporary loss. Oil fields in time become exhausted and in due season the rivers will regain their pure condition. It would require an incomparably longer time to redeem an oil and brine besodden earth.

All things considered, the recommendations set forth in the foregoing paper seem to be the wisest and most expedient that present themselves at the present time. 


\section{IN DEX.}

Page.

Alum, use of, in chemical precipitation.... 21,35 American Strawboard Company, settling basins of . . . . . . . . . . . . . vat used by, for removal of suspended matter. $17-18$

Barley straw, composition of . . . . . . . . . Bauxite as source of alum.

Benedikt, Hans, on downward velority of suspended matter.............

Beveredge, James, composition of straws, given by

Brine and oil, pollution of water by, near Marion, Ind ................. 43-50

Carbon dioxide as a precipitant $\ldots \ldots \ldots \ldots .22,35$

methods of producing.............. $32-33$

(arbon dioxide and milk of lime as a precipitant of strawboard refuse ...... $23,3 \pi$

Curbon-dioxide distributor, figure showing-

('ellulose, chemical formula for ............

in straws, percentages of ..............

Chemical precipitation as means of purification of water. ....... 20-23, 27-32,34

Coagulants used in chemical precipitation . 21-23 (opperas, use of, in chemical precipitation. 22

Disposal of strawboard waste; experiments on ........................ 18-35

of strawboard waste, methods of ..... 15-18

Distributors, figures showing........... 24

Drying, process of, in making strawboard. . 14-15

Fsparto grass, use of, in making strawboard 11 Exjeriment station at Earlham College for treating strawboard waste..... 24-25

Experiments in treatment of strawboard waste.................... 25-29

Filter heds, plate showing.............. 10 Filtering as means of disposal of strawboard waste ...................... 16-17

Filtration as means of purification of water. 19-20,

Fireproofing wood or straw, process of..... Fish, destruction of, by strawboard waste. reologic features of region about Marion, Ind

Onil

Marion, 1nd., geologic features of region about.................... $37-43$ pollution of water at, by oil and brine.. 43-50 sketch map of ................... topography and druinage of region about ...................... 36-37

Massachusetts, legislation by, against pollution of streams ............. 10

Milk of lime and carbon dioxide as a preripitant of strawboard refuse ..... 23, 235

Milk-of-lime distributor, figure showing... 24 Mine drainage, allowance of, by Pemnsylvania courts................ 111

Mississinewa liver, Indiana, enurse and character of ................ 36,37

Mixing apparatus for treating strawboard waste.................... $31-32$

Moisture in straws, differences of . . . . . . . 12-1; Müller,- - c., composition of straws given by . 11-12 Newell, F. H., letter of transmittal by .... . 7 Niagara limestone near Marion, Ind...... 41-12 Oat straw, composition of ............. 12 Ohio, strawboard statistics (1900) for..... 11 Oil and brine, pollution of water hy, near Marion, Ind . ................ $4,-; 0$

Oil wells near Marion, Ind., boring and shooting of ...................

Pasteboard. Ser Strawboard.

Pleistocene depcsits near Marion, Ind...... 3i-411 Polluted water, methods of purification of 19 . Pollution of streams by sewage, remarks on of streams hy trade waste.......... 11-11 legishation against, by great Britain by Massachusetts............ 111 sources and effects of ............. 11 of water by brine, near Marion, Ind.... 4i-.;1 by oil near Marion, Ind . ........... . $13-$ in Precipitation, chemical, as means of purification of water....... 20-23, $27-32,34$

Pulp washers, plate showing........... 12 Purification of polluted water, methods of.. 19-23 Residue contained in strawboard-waste liquor.................... 23

Rock formations, hard, near Marion, Ind... 41-43

Rotaries, action in, nature of . . . . . . . . . . . 13 steaming in, process of.............. 13-14 Rotaries and stock piles, plate showing.... 12 Rye straw, composition of ............... 12 Sections of wells at Marion, Ind ......... 38-40, 42 Sedimentation as means of purification of water.................. 19,3t Set tling and filtering as means of disposal of strawhoard waste........... $16 i-17$ 
Page.

Settling basins, plate and figure showing..14, 10, 17 sewage pollution, course of events leading to sludge, strawboard, treatment of.

steaming in rotaries, process of.

Stock piles and rotaries, plate showing. -

Strawboard, manufacture of, description of. 11-15

manufacture of, in United States, statistics of

Strawboard mill, capacity of the average ... strawboard rotaries, plate showing . . . . . . .

Strawboard settling hasin, plan of, figure showing.

Strawboard waste, analysis of treated and untreated

composition of, hefore and after passing from washers to vat.

disposal of, experiments $(11$

experiment station at Farlham college for treating.

experiments in treating.

methods of disposal of

$15-15$

mixing apparatus for treating. $81+22$

removal of, by vat. $17-18$

Strawboard-waste liquor, residue contained in.

Straws, commercial rating of

9
-34 3-14

12

\author{
11
}

1.1
12

Waste, trade, pollution of streams by. .....

Water, pollution of, by oil and hrine near

Marion, Ind .............. 43-50

Water, ground, near Marion, Ind., soturce of 41-42 Water, polluted, methods of purifica tion of - 19-23

Water supplies, pure, importance of, to municipalities ..............

Wells, sections of, at Ma rion, lnd . . . . . . 38-40, 42

Wheat straw, composition of .......... 1? 


\section{LIBRARY CATALOGUE SLIPS.}

[Mount each slip upon a selarate ard, placing the subject at the top of the second slip. The name of the series should not he repeated on the series (ard, but the additional numbers should be added, as received, to the first entry.]

\section{Sackett, Robert Lemuel.}

... The disposal of strawboard and oil-well wastes, by Robert Lemuel Sackett and Isaiah Bowman. Washington, Gov't print. off., I905.

52 I., 1 l. illus., IV 1. $23^{\mathrm{cm}}$. (U. S. Geological survey. Watersupply and irrigation paper no. 113.)

Subject series: L, Quality of water, s.

1. Water, Pollution of. 2. Strawboard waste. 3. (bil-well waste, Bowman, Isaiah.

\section{Sackett, Robert Lemuel.}

. . . The disposal of strawboard and oil-well wastes, by Robert Lemuel Sackett and Isaiah Bowman. Washington, Gov't print. off., I905.

5.2 p., I 1. illus., IV pl. 2:3m. (C. s. Geological survey. Watersupply and irrigation paper no. 113.)

sulject series: L, Quality of water, s.

1. Water, Pollution of. 2. Strawboard waste. 3. Oil-well waste, Bowman, Isaiah.

\section{U. S. Geological survey.}

Water-supply and irrigation papers.

no. II3. Sackett, R. L. The disposal of strawboard and oil-well wastes, by R. L. Sackett and I. Bowman. I905.

\section{U. S. Dept. of the Interior.}

see also

U. S. Geological survey. 
